\title{
Reuse of Domestic Greywater for the Irrigation of Food Crops
}

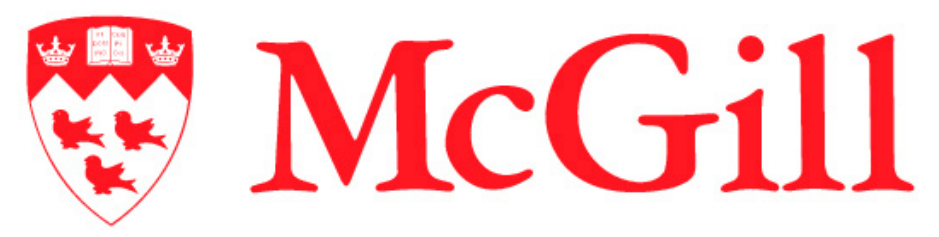

\author{
Sara Finley \\ Department of Bioresource Engineering \\ McGill University
}

August 2008

Thesis submitted to McGill University in partial fulfillment of the requirements of the Master of Science degree

(C) Sara Finley, 2008 


\begin{abstract}
As global water resources decline, reuse of domestic greywater for the irrigation of home gardens is quickly becoming widespread in many parts of the world. However, the sanitary implications of reusing greywater to water edible crops remain uncertain. This study examined the benefits and risks associated with domestic greywater reuse for the purposes of vegetable garden irrigation. Untreated (settled only) and treated (settling and slow sand filtration) greywater collected from a family home was analyzed for basic water quality parameters, over a period of eight weeks. During that time, both greywaters were used to irrigate individually potted plots of lettuce, carrots and peppers in a greenhouse. Tap water was used as control. Upon maturity, plants were harvested and the edible portions tested for fecal coliforms and fecal streptococci, common indicators for the presence of pathogenic microorganisms. Heavy metals were not detected in the greywater, but both fecal coliforms and fecal streptococci were present in high levels, averaging $4 \times 10^{5} / 100 \mathrm{~mL}$ and $2 \times 10^{3} / 100 \mathrm{~mL}$ of greywater, respectively. Despite these high counts, no significant difference in contamination levels was observed between crops irrigated with tap water, untreated and treated greywaters. Fecal coliform levels were highest in carrots and fecal streptococcus levels highest on lettuce leaves. However, contamination levels for all crops were low and do not represent a significant health risk. Plant growth and productivity were unaffected by the water quality, owing to the low $\mathrm{N}$, $\mathrm{P}$ and $\mathrm{K}$ levels of the greywater. These results reinforce the potential of domestic greywater as an alternative irrigation source.
\end{abstract}




\section{Résumé}

Dans le contexte d'un déclin et d'une perte de fiabilité des ressources hydriques du globe, la réutilisation des eaux grises (eaux le lavage) domestiques pour les fins d'irrigation devient une option populaire pour les ménages un peu partout dans le monde. Pourtant, les implications sanitaires d'une telle pratique pour l'irrigation des plantes comestibles ne sont pas encore bien comprises. Cette étude vise à examiner les bénéfices et risques associés à la réutilisation des eaux grises pour arroser les jardins potagers domestiques. Il met son focus sur la possibilité de contamination des légumes par des organismes pathogéniques et les métaux lourdes qui peuvent être présents dans les refuts domestiques. Les eaux grises d'une famille montréalaise ont été collectionnés et analysés pour des paramètres de base, y inclut les pathogènes et les métaux lourds, sur une période de 8 semaines. Pendant ce temps, ces eaux grises ont été utilisés à irriguer des plantations individuels de laitues, carottes, et poivrons rouges dans une serre de recherche. L'eau du robinet a servi comme contrôle. À la maturité, les plantes ont étés cueillis et les portions comestibles testés pour la présence des coliformes et des streptocoques fécaux, deux bactéries normalement utilisés pour indiquer la présence d'organismes pathogéniques. Puisque les métaux lourds n'étaient pas présents dans les eaux grises, ils n’ont pas étés testés dans les légumes. Les résultats ont indiqué un niveau élevé de bactéries indicateurs dans les eaux grises, mais la différence de contamination entre les légumes irrigués avec les eaux de robinet et ceux irrigués avec les eaux grises n'était pas significative. Les coliformes fécaux étaient plus concentrés sur les carottes et les streptocoques fécaux se trouvaient plus sur les feuilles de laitue. Néanmoins, les 
niveaux de contamination des aliments étaient tous peu élevés et ne représentent pas un risque sanitaire important. La croissance et la productivité des plantes n'étaient aussi pas affectées par la qualité de l'eau, dû aux faibles concentrations de N, P, et $\mathrm{K}$ dans les eaux grises. Ces résultats renforcent le potentiel des eaux grises domestiques comme source alternative d'eau pour les besoins d'irrigation. 


\section{Acknowledgements}

My sincere thanks to my supervisor, Suzelle Barrington, for her support and mentorship, and for always making time for me even when there was none. Also a big huge thanks to Darwin Lyew, for being incredibly patient with me and showing me the ropes in the laboratory.

Thanks also to my colleagues in Bioresource, Ardavan, Nida, Shilpa, Caitlin, Megan, Heidi, Qaiser, Hélène and Susan for making going to school more enjoyable. A big thanks also to Sadya who endured my relentless questions and helped me understand chemistry! Cat and Teri, thanks for making being nerdy seem like fun and stimulating my curiosity in these subjects.

Finally thanks to my family for their unwavering support and to my mom for her offers of proofreading. And to all my friends and loved ones, for encouraging me and for putting up with all my greywater talk! 


\section{Table of Contents}

ABSTRACT I

RESUME

ACKNOWLEDGEMENTS

TABLE OF CONTENTS $\quad \mathrm{V}$

CONTRIBUTION OF AUTHORS VII

LIST OF TABLES AND FIGURES VIII

LIST OF ACRONYMS AND SYMBOLS IX

1. INTRODUCTION 1

1.1 Problem statement 1

1.2 Need for research 3

1.3 Objectives and scope $\quad 4$

1.4 References 5

2. LITERATURE REVIEW 6

$\begin{array}{ll}2.1 \text { Wastewater use in agriculture } & 6\end{array}$

2.2 Separation of grey and black wastewaters 8

2.3 Composition of greywater 9

2.3.1 Microbial ecology of greywater 12

2.3.2 Indicator organisms for the measurement of pathogens in water 13

$\begin{array}{ll}2.4 \text { Options for domestic greywater use } & 14\end{array}$

$\begin{array}{ll}\text { 2.4.1 Greywater treatment } & 14\end{array}$

$\begin{array}{ll}2.4 .2 \text { Greywater storage } & 16\end{array}$

$\begin{array}{ll}\text { 2.4.3 Reuse applications } & 16\end{array}$

$\begin{array}{ll}2.5 \text { Greywater reuse for irrigation } & 17\end{array}$

$\begin{array}{ll}\text { 2.5.1 Effects on soil and plants } & 17\end{array}$

2.5.2 Pathogen transmission $\quad 20$

2.5.3 Influence of irrigation method on pathogen transmission 21

$\begin{array}{ll}\text { 2.5.4 Heavy metal transfer } & 22\end{array}$ 
2.6 Microbial risk assessment 24

2.6.1 Framework for risk analysis 24

2.6.2 Understanding crop contamination data 25

2.7 Conclusion 26

2.8 References 27

CONNECTING STATEMENT $\quad 31$

3. Reuse of domestic greywater for the irrigation of food crops 32

3.1 Abstract 32

3.2 Introduction 33

3.3 Materials and methods 36

3.3.1 Experimental materials $\quad 36$

3.3.2 Methodology 38

3.3.3 Analytical procedures $\quad 40$

3.3.4 Statistical analysis $\quad 41$

3.4 Results and discussion 41

3.4.1 Greywater characteristics $\quad 41$

3.4.2 Irrigation effects $\quad 44$

3.5 Risk analysis 47

3.6 Conclusion 49

3.7 References 51

4. SUMMARY AND DIRECTIONS FOR FUTURE RESEARCH 53

4.1 References 55

5. COMPLETE LISTING OF REFERENCES 56

APPENDIX A- COPYRIGHT WAIVER 61 


\section{Contribution of Authors}

This thesis includes a paper which has been accepted for publication in the Journal of Water, Air and Soil Pollution. Authors: Finley, S., Barrington, S., and Lyew, D. The contributions of the authors are: i) First author designed and conducted the experimental method, analyzed the data, conducted statistical analysis and composed article text. ii) Second author provided research guidance and scientific advice on the experimental design and corrected article text and figures. iii) Third author provided guidance in laboratory and microbiological techniques. 


\section{List of Tables and Figures}

Table 2.1.................................... 11

Table 3.1.................................. 37

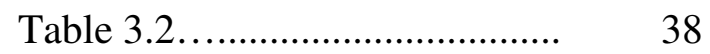

Table 3.3................................... 43

Table 3.4.................................... 49

Table 3.5 ..................................... 49

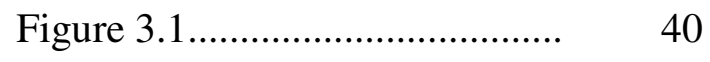

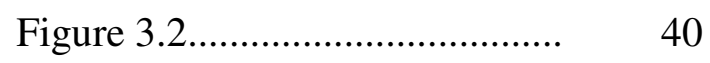

Figure 3.3.................................. 44

Figure 3.4................................... 46 


\section{List of Acronyms and Symbols}

\begin{tabular}{|c|c|}
\hline FAO & Food and Agricultural Organization of the United Nations \\
\hline WHO & World Health Organization \\
\hline QMRA & Quantitative Microbial Risk Analysis \\
\hline COD & Chemical Oxygen Demand \\
\hline BOD & Biological Oxygen Demand \\
\hline $\mathrm{N}$ & Nitrogen \\
\hline $\mathrm{P}$ & Phosphorous \\
\hline K & Potassium \\
\hline TS & Total Solids \\
\hline $\mathrm{NH}_{4}^{+}-\mathrm{N}$ & Ammonia Nitrogen \\
\hline $\mathrm{Al}$ & Aluminum \\
\hline $\mathrm{Ca}$ & Calcium \\
\hline $\mathrm{Cd}$ & Cadmium \\
\hline Co & Cobalt \\
\hline $\mathrm{Cr}$ & Chromium \\
\hline $\mathrm{Cu}$ & Copper \\
\hline $\mathrm{Mg}$ & Magnesium \\
\hline $\mathrm{Mn}$ & Manganese \\
\hline Mo & Molybdenum \\
\hline $\mathrm{Na}$ & Sodium \\
\hline $\mathrm{Pb}$ & Lead \\
\hline S & Sulfur \\
\hline $\mathrm{Fe}$ & Iron \\
\hline $\mathrm{Zn}$ & Zinc \\
\hline SAR & Sodium Absorption Ratio \\
\hline
\end{tabular}




\section{INTRODUCTION}

\subsection{Problem Statement}

We are now entering an era where abundant, clean freshwater is no longer guaranteed, even in "water-rich" countries like Canada. In many parts of the world, water scarcity is one of the most significant challenges to human health and environmental integrity. As the world's population grows and prosperity spreads, water demands increase and multiply without the possibility for an increase in supply. The mounting demand on this finite and invaluable resource has inspired creative strategies for freshwater management, including innovative techniques for wastewater recycling. Greywater reuse is one such strategy, and its usefulness to fulfill non-potable water needs should be thoroughly investigated.

Globally, over $70 \%$ of freshwater consumption is devoted to agricultural activities (FAO 2008). Recently, declining productivity of commercial farms has led international policy networks to recommend the promotion of urban and peri-urban agriculture as an escape from food crisis situations (FAO 1999). However, many households in poorer areas lack access to fertilizers and have a limited supply of fresh water. Wastewater treatment and reuse at the individual level can provide a combined solution to these problems by supplying the water and nutrients needed for household food production. Indeed, this strategy is already in use by millions of farmers worldwide and it is estimated that $10 \%$ of the world's population consumes foods irrigated with wastewater (WHO 2006). Wastewater treatment and reuse for irrigation may well hold the key to easing demand on limited freshwater reserves while improving the food production capacity of households and farms. 
However, there are significant concerns about the safety of wastewater reuse for irrigation purposes. The key issue involved is the potential for damaging effects of poor-quality water on soil, plants and humans. Water quality requirements for agricultural irrigation are a subject of much interest to researchers- in theory, agricultural water need not be of potable quality, opening the door to wastewater and surface water irrigation (WHO 2006). However, the microbial population of untreated water is very diverse, and dangerous organisms can be present. Microorganisms that can cause illness or disease, collectively known as pathogens, are usually associated with human or animal fecal matter present in wastewater and surface water sources. Irrigation water contaminated with pathogens has often been blamed for outbreaks of foodborne illness. It is important to carefully manage this risk when promoting the reuse of non-potable water sources to fulfill the water demand of agricultural irrigation activities.

In Canada, wastewater reuse is not yet common practice because of our unique situation. We are one of the last nations on earth to enjoy an abundant, inexpensive supply of clean water to meet our daily needs. Canadians are the second largest per capita consumers of freshwater in the world, surpassed only by our neighbors to the south - it is estimated that each Canadian consumes an average of 335 litres of fresh, treated water every day (Environment Canada 2001). This number is especially egregious when we compare it to 140L/person/day in Europe, or under 40L/person/day in parts of Africa and Asia (Environment Canada 2001). The consumption rate of Canadian households increases considerably in summer, when garden irrigation accounts for a large part of our water debit. Most Canadian homes incorporate at least a small yard or flower patch, and consume thousands of litres of 
water each week to keep them green. An increasing number of Canadians are also engaged in urban agriculture activities, growing food plants either as a hobby or as a means to reinforce food security. All of these activities are heavily dependent on a cheap and abundant freshwater supply. Today there are signs that Canadians' historically privileged access to fresh water may be changing. As water levels in Canadian waterways drop and pollution increases, prices are rising and efficient use of water is becoming more important to businesses, farmers and homeowners alike. As a result, interest in wastewater reuse technologies is growing rapidly.

\subsection{Need for research}

In the context of a densely populated Canadian city, full wastewater treatment and re-use is rarely feasible at the household level due to the high space requirement and technological complexity of sewage purification. Source separation of household wastewater into streams of grey- (washing) and black- (toilet) waters is a strategy that has the potential to reduce the space and investment required to achieve water reuse at the domestic level. "Greywater", which refers to used water flowing from sources such as showers, washing machines, and bathroom sinks, often represents over $2 / 3$ of household wastewater but is considered to be only weakly contaminated by pathogenic organisms and other potentially dangerous substances (WHO 2006). It has been put forward by scientists and technology companies that this water could therefore be treated with simple technology and reused for non-potable water needs such as toilet flush and outdoor irrigation. Garden watering is an obvious potential end-use for recycled greywater since irrigation does not demand drinking-water quality and can represent a high percentage of domestic water use- up to $40 \%$ of 
summer consumption in Canadian households (Environment Canada 2001).

Domestic greywater reuse schemes allow the two factors mentioned above - water wastage and high irrigation demand - to be twinned, putting excess wastewater to new use in the garden. There is also an economic benefit to this activity, as it provides significant savings in water use and sewage disposal. The health and environmental hazards of this form of water reuse are however poorly understood, and the use of greywater for watering vegetables and other edible plants is the subject of some concern. While greywater may appear benign, it can contain hazardous elements such as heavy metals, pathogenic microorganisms, and toxic chemicals that could pollute garden soils and contaminate edible crops (Eriksson et al. 2002). In order to promote water recycling practices as part of the effort to ease water demand in our growing cities, research is needed to fully understand the benefits and risks of greywater irrigation.

\subsection{Objectives and scope}

The objective of the present study was to assess the chemical and biological characteristics of domestic greywater from a Canadian home and evaluate the quality of food crops grown using this same water for irrigation. Heavy metals and pathogenic microorganisms, the specific elements of concern, were measured in both fresh greywater samples and mature crops. To replicate the conditions of a Canadian household garden, the experiment took place during the local growing season inside a research greenhouse programmed to mimic Montreal climatic conditions. Soil-level surface irrigation was employed in order to eliminate as much as possible the direct transmission route of contaminants from water to plant. The influence of crop type 
was determined by the selection of a root, leaf, and fruit crop of varying heights. Crop quality results were compared to a control group of crops grown under tapwater irrigation in identical conditions, and the comparative microbial risk of consuming the greywater-irrigated crops is presented in the final sections of the report.

The study fits into a growing body of research in the field of water reuse strategies and provides data on the quality of greywater from a Canadian home. It is one of the first focused investigations into the reuse of greywater for food crop irrigation, which may become a vital survival strategy for residents of water-scarce regions in years to come.

\subsection{References}

Environment Canada (2001). Freshwater Facts for Canada and the World. Resource Document. Government of Canada. http://www.ec.gc.ca/water/en/info /facts/e_contnt.htm. Accessed 12 February 2007

Food and Agriculture Organization of the United Nations (FAO). (1999). Resource Document. FAO Agriculture and Consumer Protection Department. http://www.fao.org /ag/magazine/9901sp2.htm. Accessed 30 March 2007

Food and Agriculture Organization of the United Nations (FAO). (2008). Resource Document. FAO Land and Water Division. ftp://ftp.fao.org/agl/aglw/factsheet_ wwf eng.pdf

Eriksson, E., Auffarth, K., Henze, M., Ledin, A. (2002). Characteristics of grey wastewater. Urban Water, 4, 85-104.

World Health Organization (WHO). (2006). Guidelines for the safe use of wastewater, excreta and greywater. Resource document. WHO. http://www.who.int/water_sanitation_health/wastewater/gsuww/en/index.html. Accessed 5 March 2007. 


\section{LITERATURE REVIEW}

\subsection{Wastewater reuse in agriculture}

In an era of dwindling water resources, the treatment and reuse of wastewater is rapidly becoming a subject of great interest to researchers. Agricultural water needs represent the lion's share of global water use, and wastewater reuse is an attractive alternative with good potential to supplement freshwater supplies. Irrigation is often the preferred end-use for reclaimed wastewater because it is produced or treated in proximity to agricultural areas and contains valuable nutrients required for plant growth. In Canada, wastewater reuse in agriculture is not a widespread practice, but it is quickly becoming more common and is currently being investigated by several municipalities as an option for agricultural and landscape irrigation (Exall 2004a).

However, wastewater can also contain dangerous elements that could negatively impact environmental and public health. Reuse of untreated wastewater in agriculture is a reality in much of the world, especially in areas where poverty restricts farmers' access to freshwater and fertilizer supplies. For this reason, much attention has been given to the health and environmental implications of raw and/or treated wastewater re-use in agricultural irrigation (I. Rosas 1984; A.C. Chang 2001; M. Salgot 2003, among others). There are a number of chemical and biological concerns associated with wastewater reuse. Most notably, reuse of sewage wastewater has the potential to transfer heavy metals, complex organic compounds, pharmaceuticals, and other dangerous elements to the environment and into the food chain (M.Salgot 2003). Pathogenic microorganisms that can be present in wastewater have the potential to cause serious health problems if ingested in crops or through 
aerosols produced by spraying activities. Pathogenic contamination on a large scale can lead to far-reaching outbreaks of foodborne illness in humans and animals.

On the other hand, wastewater contains valuable nutrients needed for plant growth, and has excellent fertilization potential for agricultural crops. Domestic and municipal wastewaters contain the macronutrients nitrogen, phosphorous, and potassium, and micronutrients such as calcium and magnesium, all of which are vital to plant and soil health. Its use can supplement or even replace commercial fertilizer inputs, saving farmers money. Wastewater reuse also benefits the environment because it allows these valuable nutrients to be diverted from the waste stream and recycled, instead of released into watercourses where they can become significant pollutants. In most areas where wastewater reuse is regulated, quality guidelines are required to ensure that the nutrient recycling potential of wastewater can be exploited while minimizing public health risks associated with its reuse.

The formulation of regulatory guidelines should be informed by thorough scientific study of wastewater contaminants and their relative risk. As pointed out by Carr et al. (2004), such guidelines should aim to balance calculated health and environmental risks with the potential benefits of wastewater reuse as an efficient use of a limited and vital resource. Multiple considerations need to be included in wastewater regulation documents to ensure that they are neither so strict that they prohibit legal use nor so relaxed that they endanger public health. For example, different types of wastewater reuse (e.g. city park irrigation, crop irrigation, etc.) should be assigned individual water-quality standards, and chemical guidelines should be set according to the particular risk associated with specific scenarios of wastewater source (e.g. domestic sources only, domestic and industrial sources, etc) 
(Salgot 2003). Guidelines also need to be informed by a comprehensive risk assessment framework, such as the Quantitative Microbial Risk Analysis (QMRA) structure explained by Petterson and Ashbolt (2003). The QMRA framework forms the basis of the World Health Organization's (WHO) publication entitled "Guidelines for the Safe Use of Wastewater, Excreta and Greywater" (formulated in 1998 and updated in 2006), to date the world's most overarching regulatory document addressing wastewater reuse. It recommends quality standards for generalized scenarios and provides local regulatory bodies with the tools necessary to establish appropriate microbiological and chemical standards specific to local wastewater sources and reuse applications (WHO, 2006).

\subsection{Separation of grey and black wastewaters}

Because meeting water quality guidelines inevitably requires an effective and reliable treatment system, (legal) wastewater reuse remains a large-scale phenomenon demanding significant technological investment and oversight by local governments or subcontractors. In order to promote wastewater reuse on a smaller scale, source separation of wastewater streams has recently received attention as a possible strategy for simplifying and decentralizing the wastewater treatment and reuse process. This model is based on the theory that excluding human solid wastes from the waste stream could greatly simplify the wastewater treatment process. From this research we see the emergence of the terms blackwater and greywater, used respectively to designate toilet waste streams and 'other' streams of water generated at the residential and commercial scale. The latter of these terms, greywater (also known as grey wastewater, graywater, or sullage water) has come to designate wastewater derived 
from handbasins, showers, baths, laundry machines, and occasionally dishwashers and kitchen sinks. Effluent water from these sources can be separated from the blackwater stream through the installation of dual reticulation plumbing. The separated greywater can then be routed to an on-site treatment system or sent to a communal greywater facility and reused for another purpose (Diaper and Sharma, 2007). Greywater recycling not only reduces the input water needs of a building, it also significantly reduces the volume of waste sent to the sewer or septic system. It is therefore especially interesting for residents of water-scarce regions and isolated buildings that are underserved by sewerage facilities.

\subsection{Composition of greywater}

In developed countries, greywater makes up about $60-70 \%$ of domestic wastewater volume (Friedler 2004). In terms of basic water quality parameters (TSS, BOD, turbdity), it is considered to be comparable to a low-or medium grade wastewater. However, there are several key differences in the composition of greywater that need to be considered in order to narrow in on the specific challenges involved in its reuse. Jefferson et al. (2004) found that, though similar in organics content to full domestic wastewater, greywater tends to contain fewer solids and is less turbid than full domestic wastewater, suggesting that more of its contaminants are dissolved. The same study also suggested that the COD:BOD ratio in greywater can approach 4:1, much higher than that of domestic wastewater, which is typically around 2:1. Because it is sourced largely from washing activities, greywater is also richer in surfactants, which in one study reached up to $60 \mathrm{mg} / \mathrm{L}$ (Gross et al. 2005). Soaps and detergents are often alkaline, so the $\mathrm{pH}$ of greywater tends to be in the 
range of 7-8 (Jefferson et al. 2004). And unlike wastewater that can contain high concentrations of $\mathrm{N}, \mathrm{P}$, and $\mathrm{K}$, only minor quantities of nutrients have been detected in greywater samples, rarely exceeding $5 \mathrm{mg} / \mathrm{L}$ (Surendran and Wheatley 1998, Jefferson et al. 2004). In terms of microbiology, however, the two streams can be quite similar, and contain analogous species of microorganisms (Ottosson 2005). With respect to detected levels of organisms used to signal pathogenicity, including faecal coliforms, enterococci, and bacteriophages, greywater has been found to be only mildly less (Jefferson et al. 2004, Casanova et al. 2001), and in one study even more (Brandes 1978), contaminated than full wastewater.

Greywater composition varies widely from household to household, depending on the personal habits of residents and the products used in the home. For example, a household that uses phosphate-free laundry detergent will produce a greywater that is much lower in phosphate-P than one that does not. Eriksson et al. (2002) found that Danish greywater samples could contain up to 900 different xenobiotic organic compounds (XOCs), depending on the cleaning and personal care products used in the home. Family makeup also plays a role- studies have found higher counts of total and fecal coliforms in greywater produced in homes occupied by adults with small children than those occupied by adults only (Rose et al. 1991, Casanova et al. 2001). Greywater characteristics from previous studies are presented in table 2.1.

Greywater characteristics also vary according to source: each fixture contributing to the greywater collection system will carry its own particular contaminant load. Friedler (2004) recommends excluding fixtures like the kitchen sink and dishwasher from a greywater system because they constitute only $25-30 \%$ of 
greywater volume but contribute nearly half of its COD content. For this reason, the least contaminated streams of household greywater are usually prioritized for reuse.

Table 2.1 Greywater characteristics from various characterization studies

\begin{tabular}{|c|c|c|c|}
\hline Parameter & $\begin{array}{l}\text { Christova- } \\
\text { Boal et al. } \\
(1996)\end{array}$ & $\begin{array}{l}\text { Friedler } \\
(2004)\end{array}$ & $\begin{array}{l}\text { Surendran } \\
\text { and } \\
\text { Wheatley } \\
(1998)\end{array}$ \\
\hline & Australia & Israel & UK \\
\hline & $\begin{array}{l}\text { Bathroom } \\
\text { and Laundry }\end{array}$ & $\begin{array}{l}\text { Shower and } \\
\text { Laundry }\end{array}$ & $\begin{array}{l}\text { Shower and } \\
\text { Laundry }\end{array}$ \\
\hline $\mathrm{pH}$ & $6.4-10$ & $7.4-7.5$ & $7.6-8.1$ \\
\hline $\mathrm{TS}(\mathrm{mg} / \mathrm{l})$ & $\mathrm{NT}^{\mathrm{a}}$ & $\begin{array}{l}1090- \\
2021\end{array}$ & $631-658$ \\
\hline $\mathrm{COD}(\mathrm{mg} / \mathrm{l})$ & NT & $319-996$ & $424-725$ \\
\hline $\mathrm{NH}_{4}{ }^{+}-\mathrm{N} \quad(\mathrm{mg} / \mathrm{l})$ & $<0.1-15$ & $1.2-4.9$ & $1.56-10.7$ \\
\hline $\mathrm{P}(\mathrm{mg} / \mathrm{l})$ & $0.062-42$ & $3.3-55.0$ & $1.63-101$ \\
\hline $\mathrm{K}(\mathrm{mg} / \mathrm{l})$ & NT & NT & NT \\
\hline $\mathrm{Al}(\mathrm{mg} / \mathrm{l})$ & $<1.0-21$ & NT & NT \\
\hline $\mathrm{Ca}(\mathrm{mg} / \mathrm{l})$ & $3.5-12$ & NT & NT \\
\hline $\mathrm{Cd}(\mathrm{mg} / \mathrm{l})$ & $<0.001$ & NT & $<0.001$ \\
\hline Co (mg/l) & NT & NT & NT \\
\hline $\mathrm{Cr}(\mathrm{mg} / \mathrm{l})$ & NT & NT & NT \\
\hline $\mathrm{Cu}(\mathrm{mg} / \mathrm{l})$ & $<0.05-0.27$ & NT & $0.11-0.32$ \\
\hline $\operatorname{Mg}(\mathrm{mg} / \mathrm{l})$ & $1.1-2.9$ & NT & NT \\
\hline $\mathrm{Mn}(\mathrm{mg} / \mathrm{l})$ & NT & NT & NT \\
\hline Mo (mg/l) & NT & NT & NT \\
\hline $\mathrm{Na}(\mathrm{mg} / \mathrm{l})$ & $7.4-480$ & $151-530$ & NT \\
\hline $\mathrm{Pb}(\mathrm{mg} / \mathrm{l})$ & NT & NT & $0.003-0.03$ \\
\hline $\mathrm{S}(\mathrm{mg} / \mathrm{l})$ & $1.2-40$ & NT & NT \\
\hline $\mathrm{Fe}(\mathrm{mg} / \mathrm{l})$ & $0.29-1.1$ & NT & NT \\
\hline $\mathrm{Zn}(\mathrm{mg} / \mathrm{l})$ & $0.09-6.3$ & NT & $0.059-0.31$ \\
\hline SAR & NT & NT & NT \\
\hline $\begin{array}{l}\text { Fecal coliform } \\
\left(\mathrm{CFU}^{\mathrm{b}} / 100 \mathrm{ml}\right)\end{array}$ & $\begin{array}{l}110- \\
3.3 \mathrm{E}+03\end{array}$ & $4 \mathrm{E}+06$ & $600-728$ \\
\hline $\begin{array}{l}\text { Fecal streptococci } \\
(\mathrm{CFU} / 100 \mathrm{ml})\end{array}$ & $23-2.4 \mathrm{E}+03$ & NT & NT \\
\hline
\end{tabular}




\subsubsection{Microbial ecology of greywater}

Microbiological characteristics of household greywater have received much attention in recent research (Birks et al. 2007, Dixon et al. 1999, Ottosson 2003). Because of their capacity to cause human illness, microbial pathogens are often considered the most significant health concern associated with greywater reuse. Despite early assumptions that greywater was relatively free of dangerous bacteria due to its exclusion of fecal solids, several studies have found a total and fecal coliform load nearly equal to that of full wastewater (Ottosson 2003, Rose et al.1991). Reviews of various characterization studies that include microbial parameters (Eriksson et al. 2002, Lazarova et al. 2003) show that kitchen sink and dishwater effluent are often the most highly contaminated due to the presence of food and grease particles and warn of high salmonella counts in these streams. Other sources, such as shower, hand basin, and washing machine are the principal contributors of organisms of fecal origin, attributable to the washing of soiled clothing or diapers, hand washing after toilet use, and showering. Rose, Sun, Gerba and Sinclair (1991) found that the total coliform count of used shower water was higher than that of laundry wash and rinse water, averaging respectively $10^{5}, 199$, and $56 \mathrm{cfu} / 100 \mathrm{~mL}$. Ottosson (2003) outlines the full spectrum of hazardous microbial agents potentially present in household greywater and provides an outline for assessing the health risks they represent. Pathogenic organisms identified include fecal bacteria, campylobacter, salmonella, legionella, Enteric viruses (especially rotavirus), and protozoa, including giardia and cryptosporidium. 


\subsubsection{Indicator organisms for the measurement of pathogens in water}

Testing for the full spectrum of individual pathogens is a very timeconsuming and costly procedure. Most water quality studies that include microbial parameters use fecal bacteria, commonly the fecal coliform group or E.Coli in particular, as indicators for the presence of pathogenic organisms in water. This is also the standard practice for surface and recreational water testing, which uses concentrations of total coliforms, fecal coliforms, and E.Coli as the basis for water quality standards. The use of indicators to measure pathogen contamination is however a source of significant debate in the field, since some scientists believe that the use of fecal coliforms or E.Coli as indicator organisms may lead to an overestimation of the pathogen count of water samples. With respect to greywater, Ottosson (2005) suggests that Coliforms and E.Coli may grow quickly in treatment and storage systems due to elevated levels of easily degraded organic compounds in greywater, thereby exaggerating the actual pathogen content. Fecal streptococci bacteria, and enterococci in particular, have been recommended as a more suitable indicator organism than coliform bacteria because they are less likely to regrow in treated water and are well correlated with rotavirus risk (Ottosson, 2005). Harwood et al. however found no significant relationship between common indicator organisms (including total and fecal coliforms, enterococci, and coliphages) and pathogenic microorganisms of concern in their 2005 study of treated and untreated wastewater samples. Similarily, Birks (2005) found no direct correlation between indicator organism (E.Coli and Enterococcus) numbers and those of true pathogens (Salmonella veltereden, Giardia, E.Coli H0157: H7 and others) in greywater samples. 
Ottosson and Stenström (2003) suggested that indicator organisms including fecal coliforms and enterococci could overestimate pathogen concentrations in greywater by $100-1000$ fold as compared to the chemical biomarkers coprostanol and cholesterol. Nevertheless, indicator organisms are an important barometer of microbial population and continue to be the standard method of measuring pathogen activity in studies of this kind.

\subsection{Options for domestic greywater reuse}

Since the emergence of source separation technology, it has been generally assumed that because greywater excludes toilet wastes, it should be technologically simpler and also more space-efficient to treat and recycle at the household and community level (Eriksson et al. 2002). While recent research has cast doubt on the first assumption, the second remains - because of the exclusion of solid human wastes, greywater treatment can be achieved on less land than that required for full wastewater treatment (Toze 2006). This factor makes greywater treatment and reuse feasible at the individual household scale, even in urban settings and multi-unit dwellings. On the demand side, multiple end-uses for recycled greywater have been identified for both indoor and outdoor reuse. These include toilet flushing, laundry, and garden irrigation at the household level, and cooling, firefighting, and industrial washing at the commercial scale. Especially in water-scarce regions of the world, greywater recycling is increasingly common and commercial treatment and recirculation technologies are emerging rapidly onto the market. 


\subsubsection{Greywater treatment}

In order to minimize potential negative impacts, it is strongly recommended that greywater be treated before reuse. Treatment systems for greywater exist in many forms, varying in their complexity, treatment method, and location within or outside the home, and should be designed in accordance with greywater source, quality, site specifications, and reuse patterns. Greywater treatment systems range in sophistication from simple branched-drain garden irrigation networks to full tertiary treatment systems that can filter water to nearly potable levels of quality.

While greywater treatment is a relatively new concept in Canada, it has been practiced for several years in places where water is less abundant or expensive to use. In the southern US, Australia, and many Middle Eastern countries, simple greywater diverting schemes are common as a means of irrigating landscape plants in arid regions. In Germany and Scandinavia, sophisticated greywater treatment systems that involve active aeration are increasingly widespread, made popular by high water prices. Many different treatment mechanisms have been studied, with varying degrees of success. Nolde (2000) recommends aerated biological treatment, while Pidou et al. (2007) received good results with chemical treatment involving coagulation and magnetic ion exchange. Hernandez-Leal et al. experimented with anaerobic greywater treatment in their 2007 study and found it less effective than comparable aerobic processes, likely because of the interference of surfactants with anaerobic bacteria. Whatever the treatment method, complete system design ideally includes a tertiary disinfection stage, usually either chlorine or UV radiation, to protect against bacterial re-growth in treated water. To date, there is no generally accepted design for greywater treatment systems, but several manufacturers around 
the globe provide plug-and-go solutions for homeowners, indicating that some private sector researchers may have found effective, safe solutions for greywater recycling.

\subsubsection{Greywater storage}

Storage of greywater prior to reuse is discouraged because it can affect the pathogen load of both raw and treated greywater. Dixon et al. (2000) tested a model for predicting quality changes in stored greywater, based on observed processes of settlement of suspended solids, aerobic microbial growth, anaerobic release of soluble COD from settled organic matter, and atmospheric re-aeration. The study suggests that storage of greywater for $24 \mathrm{~h}$ could potentially improve water quality, but storage for more than $48 \mathrm{~h}$ could seriously deplete dissolved oxygen (DO) levels and lead to what they call "aesthetic problems", including anaerobic processes and associated smells. Rose et al. (1991) found a 1-2 log increase in total and fecal coliform counts over the first $48 \mathrm{~h}$ of greywater storage.

\subsubsection{Reuse applications}

Possible applications identified for the reuse of greywater at the household level include most commonly toilet flushing and lawn and/or garden irrigation. These two reuse applications alone have the potential to significantly reduce domestic water consumption, since toilet flush and outdoor watering can respectively represent 30 and 40 percent of daily water needs during summer months (Environment Canada 2001). Potential impacts of these most common forms of greywater reuse have been outlined by Christova-Boal et al. (1996). With regard to reuse for toilet flush water, possible hazards include physical clogging of toilet inlet pipes and anaerobic 
decomposition of insufficiently treated water in the toilet tank. Lazarova, Hills, and Birks nevertheless emphasize the appropriateness of toilet-flushing as an end-use for recycled greywater in a 2003 review that outlines successful examples of water reuse for toilet flushing in large developments around the world.

\subsection{Greywater reuse for irrigation}

Garden and landscape irrigation is by far the most common mode of domestic greywater reuse (Madungwe and Sakuringwa 2007). Research into the implications of greywater reuse for irrigation often focuses on physical properties of the greywater that could potentially affect the long-term quality and productivity of soils. Elements of health and environmental significance that become important when greywater is discharged outdoors have been identified by Toze (2005) and Roesner et al. (2006). Environmentally important factors include pathogens, $\mathrm{pH}$, salinity, metals and organic chemicals that could accumulate in receiving soils (Roesner et al. 2006). Of these, enteric pathogens are identified as the most significant direct risk to human health, especially when there is potential for residents to come into direct contact with the re-circulated water.

\subsubsection{Effects on soil and plants}

There are few studies that focus exclusively on greywater irrigation, and many of these are short-term studies in which the authors only speculate about possible long-term impacts. Wielshafran et al. (2006) suggest that irrigation with insufficiently treated, surfactant-rich greywater could cause soil to take on hydrophobic properties. Christova-Boal et al. (1996) propose that irrigation with 
greywater could adversely affect the productivity of receiving soils over the long term due to high levels of sodium, zinc, and aluminum, high SAR values, and excessive alkalinity. In a 2006 review paper, Water Environment Research Foundation (WERF) scientists summarized the potential damaging effects of landscape irrigation with household greywater (Roesner et al. 2006). The report emphasizes that greywater effects on soil will vary greatly depending on water composition, the degradation rate of chemical components, sorption, loading rates, soil types, leaching, and plant uptake. It suggests that greywater irrigation could lead to direct effects on soil chemistry, such as elevated $\mathrm{pH}$, excessive salinity, or a buildup of organic compounds, and to indirect effects, most notably the modification of microbial activity in the soil due to the increased availability of organic carbon in greywater constituents (Roesner et al. 2006).

There is however a lack of experiential research into the real effects of greywater irrigation on soil and plants. Few long-term studies exist to evaluate the compounded effects of greywater irrigation on receiving soils or crops, but some information can be gleaned from wastewater irrigation studies of a similar nature. Among these, one study by Filip et al. (2000) examined the characteristics of farm soil plots after 100 years of continuous irrigation with municipal wastewater and found that organic content, microbial biomass, and ATP (indicating the presence and density of active microbes) were higher in wastewater-irrigated soils than in control groups that had not received wastewater irrigation. Mapanda et al. (2005) tested domestic wastewater-receiving soils in three Zimbabwean gardens for accumulation of heavy metals and found a moderate to strong enrichment in $\mathrm{Cr}, \mathrm{Zn}$, and $\mathrm{Cu}$ over more than 10 years of irrigation. Another study followed the abundance of arbuscular 
mycorrhizal spores in two different types of soil irrigated with wastewater over 90 years, and found a significant decrease in spore numbers as compared to control plots but no significant difference in phosphorous or heavy metal concentrations (OrtegaLarrocea et al, 2000). Studies of this kind are highly dependent on soil type, parameters of study, wastewater source, and crop type, and are therefore difficult to synthesize. They do however tend to agree that nutrients and heavy metals in irrigation water are important factors affecting the long-term productivity of soils and should be closely monitored. These elements should therefore be included in future greywater irrigation experiments.

Sludge application on agricultural lands is another widespread practice that has the potential to directly populate receiving soils with pathogens and other toxic elements, which may in turn affect the quality of crops produced. Research into the effects of sludge (also known as biosolids) application to agricultural lands may therefore provide valuable insight into the potential effects of greywater reuse. Like grey- and waste-water, municipal sludges have been found to harbour several hazardous microorganisms, including E.Coli, listeria and coliform species, salmonella and enteric viruses, even in their dried form (Gerba and Smith 2005). A connection to crop quality was established by Tierney, Sullivan and Larkin (1977) who found that the incorporation of sludge spiked with Poliovirus into farm soils led to an increased presence of this enterovirus on the surface of radish tops and lettuces, and by Al-Ghazali et al. (2000) who traced listeria species from sludge cake applications to the surface of alfalfa and parsley plants. However, a quantitative risk assessment by Gale (2004) modeled the transmission of salmonella, Listeria monocytogenes, campylobacters, Escherichia coli O157, Cryptosporidium parvum, 
Giardia, and enteroviruses from root crops grown in sludge-amended soils in the UK, and found the forecast annual health risk to consumers to be remote, in the order of one incident per year. The nature of the relationship between the addition of pathogens into agricultural soils (through wastewater and sewage sludge reuse, and potentially greywater irrigation) and the real pathogenic contamination of edible crops is not subject to generalization. It can depend on a number of factors, described below.

\subsubsection{Pathogen transmission}

Of all the possible hazards associated with wastewater and greywater reuse, the contamination of crops and soil by potentially pathogen-rich reuse water is often singled out as the most significant source of concern for human health (Roesner et al. 2006, Ottosson 2003, Christova-Boal et al. 1996). Indeed, it is based on these risks that guidelines for reuse water are set. Yet the relationship between water and crop contamination remains unclear. One study by Jackson et al. (2006) found no significant difference in bacterial levels on plant surfaces grown in plots irrigated with greywater, tap water, or hydroponic solution despite high bacterial counts in the greywater and none in the other treatment waters. Other studies find a direct link, such as that of Armon et al. (1994), which draws a direct correlation between crop contamination and the quality of effluent sprayed on test plots. Even when edible portions of a crop are not affected, soil contamination can itself be dangerous, especially at the level of the household garden where human contact with the soil is likely.

It is difficult to predict the movement and survival of pathogenic organisms in 
soil. A review paper by Santamaria and Toranzos (2003) suggests that enteric pathogens applied to the soil are most likely to travel and spread under wet conditions, in clay soils, and under low temperature and $\mathrm{pH}$ conditions. The survival of pathogens in the soil ecology is individual to each organism but can be significantfor example, Jiang et al. (2002) found that Escherichia coli O157:H7, a dangerous pathogen often found to be the culprit for foodborne disease outbreaks, can survive up to 231 days in warm soil. In crop studies, the microbial pollution of soil becomes important when it comes to differentiating between the potential for contamination of root, leaf, and fruit crops. Because root crops are in constant contact with the soil, they are more likely to show signs of contamination when bacteria-rich irrigation water is used. Indeed, Rosas et al. (1984) found that up to $94 \%$ of the fecal coliforms found in wastewater-irrigated crops were isolated from the root section of the plant.

\subsubsection{Influence of irrigation method on pathogen transmission}

Irrigation method is another factor of considerable importance in the reuse of grey- and wastewater, especially with regards to microbial contamination in agricultural applications. Current research suggests that direct transmission of pathogenic microorganisms from contaminated irrigation water to above-ground plant surfaces is the most important health risk associated with wastewater reuse for edible and landscape plants (Gerba and Smith 2005). Since it is widely asserted that the vascular systems of plants are sterile (Mills et al. 1925), direct contact of the water with edible portions of vegetables and other food crops is the principal transmission route of pathogens from water to crop in the case of agricultural irrigation. In order to avoid the direct transmission route, many regulatory agencies recommend 
eliminating contact with wastewater (or greywater) by installing subsurface irrigation networks, which deliver water a few centimeters beneath the surface of the soil. Sadovski et al. (1978) showed that burying drip irrigation pipes reduced pathogen levels on crop surfaces to nearly undetectable levels, even under simulated epidemic concentrations of E.Coli and poliovirus in irrigation water. Covering the drip lines of normal drip irrigation lines with polyethylene covers had the same effect. Armon et al. (1994) examined the transmission of protozoan cysts onto zucchini surfaces from poor-quality irrigation water and found that spray irrigation led to considerably higher transmission than surface or subsurface applications. Similarly, Enriquez et al. (2003) tested turfgrass irrigated with bacteriophage-seeded water and found significantly lower transmission rates with the use of subsurface irrigation networks than with surface irrigation. However, pathogenic organisms may accumulate in the soil, as indicated by Casanova et al. (2001) who found greywater-irrigated soil plots to have significantly higher levels of fecal coliforms and E.Coli than freshwaterirrigated plots. The implications of a buildup of pathogenic microorganisms in receiving soils are unclear as each organism will exhibit distinct survival rates and patterns of movement in the subsurface. The potential for pathogenic contamination of underlying groundwater is also a concern and should be evaluated.

\subsubsection{Heavy metal transfer}

Although heavy metal accumulation is not considered to be among the most important concerns when it comes to greywater reuse for irrigation (Roesner et al. 2006), it is strongly associated with wastewater and sludge reuse, and therefore deserves attention in greywater studies. In contrast to bacterial contamination, 
irrigation methods are less influential on heavy metal transfer rates, since many of these elements are readily taken up by plants through the vascular system (Rattan et al. 2005). Eriksson et al. (2002) identified zinc, lead and copper as the heavy metals most likely to be present in greywater, due to leaching from pipes and other metal water fixtures. The presence of these elements is therefore assumed to be related to the corrosiveness of local tap water supplies and the composition of household plumbing infrastructure (Eriksson et al. 2002). If present in greywater used for irrigation, these elements could have adverse long-term effects on crops and soil, as evidenced by Rattan et al. (2005) who found agricultural soils irrigated with sewage water containing high heavy metals concentrations had indeed caused the accumulation of such metals as $\mathrm{Cu}, \mathrm{Pb}$, and $\mathrm{Zn}$ in the soil over a 20 -year period. According to Eriksson et al. (2002), these elements can be present in comparable quantities in greywater, with maximum values of $1.6 \mathrm{mg} / \mathrm{L} \mathrm{Zn}, 0.15 \mathrm{mg} / \mathrm{L} \mathrm{Pb}$, and $0.39 \mathrm{mg} / \mathrm{L} \mathrm{Cu}$ for greywater of mixed sources.

With regard to plant uptake of heavy metals, results will depend on several environmental conditions including soil characteristics, $\mathrm{pH}$, and crop type (Mapanda et al. 2005). Karami et al. (2009) found that sewage sludge application to wheat plots significantly increased the DPTA-extractable concentrations of $\mathrm{Pb}, \mathrm{Cd}, \mathrm{Zn}$ and $\mathrm{Cu}$ in the soils but that this increase did not correlate linearly with an increase in uptake to the plant stalks and grains in all cases. The abovementioned study by Rattan et al. (2005) found disparate rates of $\mathrm{Zn}, \mathrm{Cu}, \mathrm{Fe}, \mathrm{Ni}, \mathrm{Mn}$ and $\mathrm{Pb}$ uptake by different grain and vegetable crops grown in wastewater-irrigated plots over a period of 10 years. The health risk associated with the consumption of foods irrigated with water 
containing heavy metals must therefore be analyzed with respect to specific soil conditions and crop species.

\subsection{Microbial risk assessment}

\subsubsection{Framework for risk analysis}

A full risk analysis model takes into account social, biological and behavioral factors to provide numerical probabilities of illness related to a specific activity. The true likelihood of illness is then calculated based on historical epidemiological data. Risk analysis is crucial for government bodies because it helps them form the basis of laws and regulations that protect the public from risk. The process of risk analysis involves three steps: risk assessment, wherein the risk is identified; risk management, wherein good practices are outlined; and risk communication, wherein individuals are notified of the risk associated with a given activity (Haas, Rose \& Gerba, 1999). Within the scope of this study, only the risk assessment step will be applicable, and will relate specifically to microbial parameters of greywater-irrigated crops. The important variables in any microbial risk assessment include:

- expected dose (number of organisms) ingested per event,

- expected number of ingestion events per person per year

- probability of infection of the organism

- likelihood of illness per incidence of infection

To simplify the risk assessment procedure for this study, data for probability of infection and likeliness of illness per incidence of infection will be based on overall values for enteric pathogenic bacteria provided by Hurst (2002). The size and frequency of ingested doses are determined on a case-by-case basis and will be 
modeled on the case study that forms the basis of this experiment. A standard risk analysis model for agricultural crops involves not only the crop quality itself but also post-harvest factors such as handling, storage, and transport conditions, which can also be significant sources of contamination (De Roever 1998). In this case, however, only the crop quality is used as a basis for risk assessment.

\subsubsection{Understanding crop contamination data}

There are no generally-accepted microbiological standards for fresh produce, but food protection agencies use their own criteria to signal potentially dangerous contamination. In its 1986 publication, the International Commission on Microbiological Specifications for Foods (ICMSF) suggested a limit of $100 \mathrm{CFU/g}$ for E.Coli on fruits and vegetables, with a sample size (n) of at least five (5) and with no two (2) samples exceeding that limit in any one testing period. Since E.Coli is incorporated in the fecal coliform group, this threshold can be translated into a conservative limit of $100 \mathrm{CFU} / \mathrm{g}$ for fecal coliforms. There is no such suggested standard for fecal streptococci numbers, and the real danger of their presence in foods is subject to debate. Fecal streptococci are naturally-occurring in some foods, most notably meats and cheeses, and their relationship to other pathogenic organisms is unclear. While some strains are used as probiotic cultures in health foods, others are suspected, though not confirmed, to be responsible for past outbreaks of foodborne illness (Franz et al. 1999). In the microbial examination of foods, pathogens are often individually measured using specific media because there is less certainty in the effectiveness of indicator organisms to signal the presence of other pathogens (Gracias and McKillip, 2004). Because both indicator organisms chosen to measure 
the water quality in this study (fecal coliform and fecal streptococci) also have the potential to become food-borne pathogens if contamination occurs, a risk assessment based on the prevalence of these two organisms should give a good indication of the relative safety of the products under investigation.

\subsection{Conclusion}

Even when hazards have been recognized, it is important to comprehensively measure and balance the real and perceived risks associated with activities that allow us to use an essential resource more efficiently. Greywater reuse for edible crop irrigation could become a popular coping strategy in parts of the world where freshwater is in short supply and local food production is necessary to combat food insecurity. However, scant attention has been given to this growing field of activity in scientific research, and the real implications for the health of crops and humans remain unclear.

In order to most closely approximate the reuse of greywater at the level of a Canadian household, this study aimed to reproduce the climate, irrigation practices, and consumption patterns of a typical home vegetable garden. 'Real-life' greywater was used for daily irrigation and the crops were tested in their uncooked, unwashed state. While many factors are involved in the transmission of dangerous elements from the greywater to edible portions of plants, this study concentrates on the most fundamental, that is, the actual detected contamination of edible portions of crops eaten raw and the risk that it poses to the people that consume them. Other factors such as the buildup of hazardous agents in garden soils, pollution of groundwater, potential water savings of greywater reuse, and many others are beyond the scope of 
this study but should also be prioritized for research. It is vital that we establish safe practices for reusing our water in order to remain healthy and productive in a waterscarce future.

\subsection{References}

Al-Ghazali, M.R., Al-Azawi, S.K. (1990). Listeria monocytogenes contamination of crops grown on soil treated with sewage sludge cake. Journal of Applied Bacteriology, 69, 642-647.

Armon, R., Dosoretz, C.G., Azov, Y., Shelef, G. (1994). Residual contamination of crops irrigated with effluent of different qualities: a field study. Water Science and Technology, 30(9), 239-248.

Birks, R., \& Hills, S. (2007). Characterisation of indicator organisms and pathogens in domestic greywater for recycling. Environmental Monitoring and Assessment, 129(1-3), 61-69.

Brandes, M. (1978). Characteristics of effluents from separate septic tanks treating grey water and black water from the same house. Journal Water Pollution Control Federation, 50(11), 2547-2559.

Casanova, L.M., Gerba, C.P., Karpiscak, M. (2001). Chemical and microbial characterization of household graywater. Journal Of Environmental Science And Health Part A-Toxic/Hazardous Substances \& Environmental Engineering, 36(4), $395-401$

Christova-Boal, D., Eden, R.E., McFarlane, S. (1996). An investigation into greywater reuse for urban residential properties. Desalination, 106, 391-397.

Carr, R. M., Blumenthal, U.J., Mara, D. D. (2004). Guidelines for the safe use of wastewater in agriculture: revisiting WHO guidelines. Water Science and Technology, 50(2), 31-38.

Chang, A.C., Pan, G., Page, A.L., Asano, T. (2001). Developing Human Health-related Chemical Guidelines for Reclaimed Waster and Sewage Sludge Applications in Agriculture. Resource Document. World Health Organization. http://www.who.int/ water_sanitation_health/wastewater/gwwuchemicals.pdf. Accessed February 20, 2007.

De Roever, C. (1998). Microbiological Safety Evaluations and Recommendations on Fresh Produce. Food Control, 9(6), 321-347.

Diaper, C., \& Sharma, A. (2007). Innovative sewerage solutions for small rural towns. Water Science \& Technology, 56 (5), 97-103.

Dixon, A., Butler, D., Fewkes, A., Robinson, M. (2000). Measurement and modelling of quality changes in stored untreated grey water. Urban Water, 1, 293-306.

Environment Canada (2001). Freshwater Facts for Canada and the World. Resource Document. Government of Canada http://www.ec.gc.ca/water/en/info /facts/e_contnt.htm. Accessed 12 February 2007

Enriquez, C., Alum, A., Suarez-Rey, E.M., Choi, C.Y., Oron, G., Gerba, C.P. (2003). Bacteriophages MS2 and PRD1 in turfgrass by subsurface drip irrigation. Journal of 
Environmental Engineering-ASCE, 129(9), 852-857.

Eriksson, E., Auffarth, K., Henze, M., Ledin, A. (2002). Characteristics of grey wastewater. Urban Water, 4, 85-104.

Exall, K., Marsalek, J., Schaefer, K. (2004). A Review of Water Reuse and Recycling, with Reference to Canadian Practice and Potential: 1. Incentives and Implementation. Water Quality Research Journal of Canada, 39(1), 1-12.

Exall, K. (2004). A review of water reuse and recycling, with reference to Canadian practice and potential: 2. Applications. Water Quality Research Journal of Canada, 39(1), 13-28.

Filip, Z., Kanazawa, S., Berthelin, J. (2000). Distribution of Microorganisms, Biomass ATP, and Enzyme activities in Organic and Mineral Particles of a Long-Term Wastewater Irrigated Soil. Journal of Plant Nutrition and Soil Science, 163(2), 7.

Franz, C.M.A.P., Holzapfel, W.H., Stiles, M.E. (1999). Enterococci at the crossroads of food safety? International Journal of Food Microbiology, 47, 1-24.

Friedler, E. (2004). Quality of individual domestic greywater streams and its implication for on-site treatment and reuse possibilities. Environmental Technology, 25, 997-1008.

Gale, P. (2005). Land application of treated sewage sludge: quantifying pathogen risks from consumption of crops. Journal of Applied Microbiology, 98, 380-396.

Gerba, C.P., \& Smith, J.E. (2005). Sources of pathogenic microorganisms and their fate during land application of wastes. Journal Of Environmental Quality, 34, 4248.

Gracias, K.S., \& McKillip, J.L. (2004). A review of conventional detection and enumeration methods for pathogenic bacteria in food. Canadian Journal of Microbiology, 50, 883-890.

Gross, A., Azulai, N., Oron, G., Ronen, Z., Arnold, M. (2005). Environmental impact and health risks associated with greywater irrigation: a case study. Water science and technology, 52(8),161-169.

Haas, C.N., Rose, J.B., Gerba, C.P. (1999). Quantitative Microbial Risk Assessment. New York, NY: John Wiley and Sons.

Hernández-Leal, L., Zeeman, G., Temmink, H., Buisman, C. (2007). Characterisation and biological treatment of greywater. Water Science \& Technology, 56(5), 193200.

Hurst, C.J. (2002). Estimating the risk of infectious disease associated with pathogens in water. In Hurst, C.J., Crawford, R.L., Knudson, G.R., McInerney, M.J. and Stetzenbach, L.D. (eds.), Manual of Environmental Microbiology (2nd edn.), pp.309-319. Washington, DC: ASM Press.

International Commission on Microbiological Specifications for Foods. (1986). Micro-organisms in foods 2: Sampling for microbiological analysis: Principles and specific applications. Toronto, ON: University of Toronto Press.

Jackson, S., Rodda, N., Salukazana, L. (2006). Microbiological assessment of food crops irrigated with domestic greywater. Water SA, 32(5), 700-704.

Jefferson, B., Palmer, A., Jeffrey, P., Stuetz, R., Judd, S. (2004). Grey water characterisation and its impact on the selection and operation of technologies for urban reuse. Water Science and Technology, 50(2), 157-164.

Jiang X., Morgan, J., Doyle, M.P. (2002). Fate of Escherichia coli O157: H7 in ManureAmended Soil. Applied and Environmental Microbiology, 68(5), 2605-2609.

Karami, M., Afyuni, M., Rezainejad, Y., Schulin, R. (2008). Heavy metal uptake by wheat 
from a sewage sludge-amended calcareous soil. Nutrient Cycling in Agroecosystems, 83, $51-61$.

Lazarova, V., Hills, S., Birks, R. (2003). Using recycled water for non-potable, urban uses: a review with particular reference to toilet flushing. Water science and Technology- Water Supply, 3(4), 69-77.

Mapanda, F., Mangwayana, E.N., Nyamangara, J., Giller, K.E. (2005). The effect of long-term irrigation using wastewater on heavy metal contents of soils under vegetables in Harare, Zimbabwe. Agriculture, Ecosystems and Environment, 107, 151-165.

Madungwe, E. \& Sakuringwa, S. (2007). Greywater reuse: A strategy for water demand management in Harare? Physics and Chemistry of the Earth, 32(15-18), 1231-1236.

Mills, R.G., Bartlett C.L., Kessel, J.F. (1925). The penetration of fruits and vegetables by bacteria and other particulate matter, and the resistance of bacteria, protozoan cysts and helminth ova to common disinfection methods. American Journal of Epidemiology, 5(5), 559-579.

Nolde, E. (1999). Greywater reuse systems for toilet flushing in multi-storey buildings-over ten years experience in Berlin. Urban Water, 1, 275-284.

Ottosson, J. (2003). Hygiene aspects of greywater and greywater reuse. Royal Institute of technology (KTH)/Swedish Institute for Infectious Disease Control (SMI), Stockholm: Licentiate Thesis.

Ottosson, J., \& Stenström, T.A. (2003). Growth and reduction of microorganisms in sediments collected from a greywater treatment system. Letters in Applied Microbiology, $36(3), 168-72$

Ottosson, J. (2005). Comparative Analysis of Pathogen Occurrence in WastewaterManagement strategies for barrier function and microbial control. Royal Institute of technology (KTH)/Swedish Institute for Infectious Disease Control (SMI), Stockholm: Doctorate Thesis.

Petterson, S.A., \& Ashbolt, N.J. (2003). WHO Guidelines for the Safe Use of Wastewater and Excreta in Agriculture: Microbial Risk Assessment Section. Resource document. http://www.who.int/entity/water_sanitation_health/wastewater/mrareview.pdf. Accessed 26 April 2007.

Pidou, M., Avery, L., Stephenson, T., Jeffrey, P., Parsons, S., Liu, et al. (2008). Chemical solutions for greywater recycling. Chemosphere, 71, 147-155.

Rattan, R.K., Datta, S.P., Chhonkar, P.K., Suribabu, K. (2005). Long-term impact of irrigation with sewage effluents on heavy metal content in soils, crops and groundwater - a case study. Agriculture, Ecosystems and Environment, 109, 310-322.

Roesner, L., Qian, Y., Criswell, M., Stromberger, M., Klein, S. (1994). Long-Term Effects of Landscape Irrigation Using Household Graywater- Literature Review and Synthesis. Resource Document. Water Environment Research Foundation. http://www.cleaning101.com/files/SDA_WERF_Graywater_2006.pdf. Accessed 20 January 2007

Rosas, I., Baez, A., Coutino, M. (1984). Bacteriological Quality of Crops Irrigated with Wastewater in the Xochimilco Plots, Mexico City, Mexico. Applied and Environmental Microbiology, 47(5), 1074-1079. 
Rose, J.B., Sun, G-S., Gerba, C.P., Sinclair, N.A. (1991). Microbial quality and persistence of enteric pathogens in graywater from various household sources. Water Research, 25(1), 37-42.

Sadovski, A.Y., Fattal, B., Goldberg, D., Katzenelson, E. (1978). High levels of microbial contamination of vegetables irrigated with wastewater by the drip method. Applied and Environmental Microbiology, 36(6), 824-830.

Santamaría, J., \& Toranzos, G.A. (2003). Enteric pathogens and soil: a short review. International Microbiology, 6, 5-9.

Salgot, M., Vergés, C., Angelakis, A.N. (2003). Risk assessment in wastewater recycling and reuse. Water science and Technology- Water Supply, 3(4), 301-308.

Salgot, M., Huertas, E., Weber, S., Dott, W., Hollender, J. (2006). Wastewater reuse and risk: definition of key objectives. Desalination, 187, 29-40.

Surendran, S., \& Wheatley, A.D. (1998). Grey-water reclamation for non-potable reuse. Journal of the Chartered Institution of Water and Environmental Management, $12,406-413$.

Tierney, J., Sullivan, R., Larkin, E. (1977). Persistence of poliovirus 1 in soil and on vegetables grown in soil previously flooded with inoculated sewage sludge or effluent. Applied and Environmental Biology, 33(1), 109-113.

Toze, S. (2006). Reuse of effluent water-benefits and risks. Agricultural Water Management, 80, 147-159.

World Health Organization (WHO). (2006). Guidelines for the safe use of wastewater, excreta and greywater. Resource document. WHO. http://www.who.int/water_sanitation_health/wastewater/gsuww/en/index.html. Accessed 5 March 2007.

Wielshafran, A., Ronen, Z., Weisbrod, N., Adar, E., Gross, A. (2006). Potential changes in soil properties following irrigation with surfactant-rich greywater. Ecological Engineering, 26, 348-354. 


\section{CONNECTING STATEMENT}

Chapter 3 addresses the effects of greywater irrigation on the quality of vegetable crops. Greywater from a Montreal home was tested for a wide range of parameters once weekly over a period of 8 weeks in order to establish its characteristics. During this time it was used to irrigate three different types of vegetables in a research greenhouse. The mature crops were tested for microbial contamination and results were compared to a control group watered with municipal tap water. The dry mass of crops was also tested to determine crop productivity.

This paper has been accepted for publication in the Journal of Water, Air and Soil Pollution. Authors: Finley, S., Barrington, S., and Lyew, D. The contributions of the authors are: i) First author designed and conducted the experimental method, analyzed the data, conducted statistical analysis and composed article text. ii) Second author provided research guidance and scientific advice on the experimental design and corrected article text and figures. iii) Third author provided guidance in laboratory and microbiological techniques. 


\section{Reuse of Domestic Greywater for the Irrigation of Food Crops Sara Finley, Suzelle Barrington and Darwin Lyew \\ Accepted for publication in the Journal of Water, Air, and Soil Pollution.} August 2008

\subsection{Abstract}

As global water resources decline, reuse of domestic greywater for the irrigation of home gardens is quickly becoming widespread in many parts of the world. However, the sanitary implications of reusing greywater to water edible crops remain uncertain. This study examined the benefits and risks associated with domestic greywater reuse for the purposes of vegetable garden irrigation. Untreated (settled only) and treated (settling and slow sand filtration) greywater collected from a family home was analyzed for basic water quality parameters, over a period of eight weeks. During that time, both greywaters were used to irrigate individually potted plots of lettuce, carrots and peppers in a greenhouse. Tap water was used as control. Upon maturity, plants were harvested and the edible portions tested for fecal coliforms and fecal streptococci, common indicators for the presence of pathogenic microorganisms. Heavy metals were not detected in the greywater, but both fecal coliforms and fecal streptococci were present in high levels, averaging $4 \mathrm{x}$ $10^{5} / 100 \mathrm{~mL}$ and $2 \times 10^{3} / 100 \mathrm{~mL}$ of greywater, respectively. Despite these high counts, no significant difference in contamination levels was observed between crops irrigated with tap water, untreated and treated greywaters. Fecal coliform levels were highest in carrots and fecal streptococcus levels highest on lettuce leaves. However, contamination levels for all crops were low and do not represent a significant health risk. Plant growth and productivity were unaffected by the water quality, owing to the 
low N, P and K levels of the greywater. These results reinforce the potential of domestic greywater as an alternative irrigation source.

\subsection{Introduction}

Domestic wastewater treatment and reuse is becoming an important field of research in a global context of increasing water scarcity and inadequate sanitation. In the developing world, insufficient water supply and poor sanitation facilities cause thousands of deaths each day, while in developed countries water wastage is often the norm and ineffective septic and wastewater treatment systems cause pollution of lakes, rivers and groundwater. In parallel, water demand continues to increase and its availability for agricultural irrigation is a limiting factor for food production in many countries. New water-use models and wastewater reuse patterns are of utmost importance in water research today.

Source separation of domestic wastewater into grey- and black-water streams is a strategy for simplifying and decentralizing the wastewater treatment and reuse

process. Greywater, which excludes toilet wastes and typically represents $60-70 \%$ of liquid waste flows (Friedler 2004), should be technologically simpler and more space-efficient to treat and/or reuse at the household and community level (Eriksson 2002). However, when compared to raw wastewaters, greywater has been found to be only mildly less contaminated (Casanova et al. 2001; Jefferson et al. 2004) and in some cases more contaminated (Brandes 1978) with hazardous agents, including pathogens and heavy metals. In all cases, it is recommended to treat greywater before reusing it. 
Landscape and agricultural irrigation are identified as logical uses for recycled greywater (Toze 2006; Christova-Boal et al. 1996). Experiences with greywater reuse for irrigation in many parts the world have been compiled by Madungwe and Sakuringwa (2007) and have shown a general net benefit in terms of water conservation, reduction in strain to wastewater facilities, food production and aquifer recharge.

Greywater reuse for irrigation is not however without its hazards, since it may contain organic and chemical compounds that can pollute the environment and pose a health risk to humans (Toze 2006; Roesner et al. 2006; Eriksson et al. 2002). The most obvious contaminants of concern include metals, pathogenic microorganisms, and complex organic compounds that may be slow to break down in the environment. Greywater characteristics are largely influenced by location, personal habits and cleaning products used in the home and can vary greatly from house to house, as demonstrated by Eriksson (2002) who discovered that over 900 different Xenobiotic Organic Compounds (XOCs) could be present in domestic greywater, depending on the detergents and personal care products used in the home. With respect to irrigation, the most prevalent risks are those associated with elevated $\mathrm{pH}$, salinity, and boron in greywater, and the potential accumulation of pathogens, metals and organic chemicals in receiving soils. While the first three factors mainly affect soil properties, the latter three can have implications for human health, especially in the irrigation of edible crops.

Few studies focus exclusively on greywater reuse for irrigation of edible crops and the potential transmission of human pathogens. One study by Jackson et al. (2006) found no significant difference in bacterial levels on plant surfaces grown in 
plots irrigated with greywater, tap water, or hydroponic solution. Field studies conducted using wastewater for vegetable irrigation have found higher bacterial counts on crop portions that mature underground or near the surface of the soil (Armon et al. 1994, Rosas et al. 1984). Since it is commonly asserted that the vascular systems of plants are sterile, direct contact of the water with edible portions is the principal transmission route of pathogens from water to crop (Gerba and Smith 2005; Mills et al. 1925). Sadovski et al. (1978) showed that burying drip irrigation pipes reduced pathogen levels on crop surfaces to nearly undetectable levels, even under simulated epidemic concentrations.

Pathogenic organisms of concern associated with greywater reuse include enterotoxigenic Escherichia Coli, Salmonella, Shigella, Legionella, and enteric viruses (Rose et al. 1991; Ottosson 2003). Fecal streptococci and fecal coliforms have been found to be the most useful indicator organisms to signal the presence of these pathogens (Ottosson 2003). While fecal coliforms have a direct correlation to fecal pollution, fecal streptococci are used as a complementary indicator because they are more resistant to environmental stress and less prone to regrowth in the environment (Ottosson 2003).

The objective of the present study was to evaluate the chemical and biological characteristics of greywater-irrigated crops of various morphologies. To address the potential for crop contamination associated with the household reuse of greywater, the project traced the transmission of indicator bacteria and other contaminants from water to plant. Soil-level irrigation was used in order to eliminate as much as possible the direct transmission route. The influence of crop type was determined by the 
selection of a root, leaf, and fruit crop of varying heights. Results are accompanied by a risk analysis.

\subsection{Materials and Methods}

\subsubsection{Experimental Materials}

Greywater originating from the showers and washing machine of a single family residence was sampled by inserting sterile sampling containers directly into the stream at two locations within a home greywater collection/treatment system. The first sampling point for the untreated greywater $\left(\mathrm{GW}_{\mathrm{u}}\right)$ was after a primary settling stage with a hydraulic retention time (HRT) of $\pm 8 \mathrm{~h}$, while the second sampling stage for the treated greywater $\left(\mathrm{GW}_{\mathrm{t}}\right)$ was after coarse filtration and treatment by slow sand filtration with a HRT of $\pm 24 \mathrm{~h}$.

The greywater sources consisted of two showers, one bathtub, and one washing machine. The house is permanently inhabited by three adults and one small child ( 2 yrs of age). The residents use primarily environmentally-friendly (biodegradable, phosphate-free) shampoos and detergents, and diapers were not washed in the machine that flows into the greywater system. Tap water for the control group was unaltered Montreal municipal water. The characteristics of the greywater and tap water used for irrigation purposes in this study are outlined in Table 1.

Potting soil for the greenhouse experiment was mixed on-site using 7.5 parts pasteurized field top soil consisting mainly of fine sand, 1 part perlite (Holiday $\left.{ }^{\circledR}\right), 1$ part vermiculite (Holiday ${ }^{\circledR}$ ) and $1 / 2$ part peat moss (sphagnum moss). The freshly mixed experimental soil is characterized in Table 2. 
Seeds and plantlets used represent the following varieties: Baby Finger carrots, Daucus carota sativa; Grand Rapids lettuce, Lactuca sativa; and Gypsy Red peppers, Capsicum annuum. The carrots represented the category of root vegetables, whereas the lettuce represented leafy vegetables with close soil contact and the peppers represented crops that mature off the ground with limited soil contact.

Table 3.1 Experimental greywater and tapwater used for irrigation

\begin{tabular}{|c|c|c|c|}
\hline Parameter & $\begin{array}{l}\text { Untreated } \\
\text { Greywater }\left(\mathrm{GW}_{\mathrm{u}}\right)\end{array}$ & $\begin{array}{l}\text { Treated } \\
\text { Greywater }\left(\mathrm{GW}_{\mathrm{t}}\right)\end{array}$ & $\begin{array}{l}\text { City of } \\
\text { Montreal } \\
\text { Tap water }\end{array}$ \\
\hline $\mathrm{pH}$ & $6.7-7.6$ & $6.9-7.9$ & $7.4-7.5$ \\
\hline $\mathrm{TS}(\mathrm{mg} / \mathrm{L})$ & $313-543$ & $330-633$ & $\mathrm{NT}^{\mathrm{a}}$ \\
\hline COD $(\mathrm{mg} / \mathrm{L})$ & $278-435$ & $161-348$ & NT \\
\hline $\mathrm{NH}_{4}^{+}-\mathrm{N}(\mathrm{mg} / \mathrm{L})^{\mathrm{b}}$ & $1.2-6.2$ & $4.1-5.1$ & NT \\
\hline $\mathrm{P}(\mathrm{mg} / \mathrm{L})$ & $0.24-1.02$ & $0.24-1.21$ & ND \\
\hline $\mathrm{K}(\mathrm{mg} / \mathrm{L})$ & $2.2-2.5$ & $0.6-4.4$ & ND \\
\hline $\mathrm{Al}(\mathrm{mg} / \mathrm{L})$ & $\mathrm{ND}^{\mathrm{c}}$ & ND & ND \\
\hline $\mathrm{Ca}(\mathrm{mg} / \mathrm{L})$ & $30-44$ & $28-44$ & $9.5-9.6$ \\
\hline $\mathrm{Cd}(\mathrm{mg} / \mathrm{L})$ & ND & ND & ND \\
\hline Co $(\mathrm{mg} / \mathrm{L})$ & ND & ND & ND \\
\hline $\mathrm{Cr}(\mathrm{mg} / \mathrm{L})$ & ND & ND & ND \\
\hline $\mathrm{Cu}(\mathrm{mg} / \mathrm{L})$ & ND & ND & ND \\
\hline $\mathrm{Mg}(\mathrm{mg} / \mathrm{L})$ & $8.0-9.9$ & $8.0-10.1$ & 2.1 \\
\hline $\mathrm{Mn}(\mathrm{mg} / \mathrm{L})$ & ND & ND & ND \\
\hline Mo (mg/L) & ND & ND & ND \\
\hline $\mathrm{Na}(\mathrm{mg} / \mathrm{L})$ & $20-27$ & $18-27$ & $18.6-18.8$ \\
\hline $\mathrm{Pb}(\mathrm{mg} / \mathrm{L})$ & ND & ND & ND \\
\hline $\mathrm{S}(\mathrm{mg} / \mathrm{L})$ & $5.0-8.8$ & $3.3-8.0$ & $6.8-7.0$ \\
\hline $\mathrm{Fe}(\mathrm{mg} / \mathrm{L})$ & 0.09 & $0.08-0.45$ & ND \\
\hline $\mathrm{Zn}(\mathrm{mg} / \mathrm{L})$ & $0.04-0.42$ & $0.01-0.38$ & ND \\
\hline SAR & $4.2-5.8$ & $3.9-6.1$ & $7.7-7.8$ \\
\hline $\begin{array}{l}\text { Fecal coliform } \\
\left(\mathrm{CFU}^{\mathrm{d}} / 100 \mathrm{~mL}\right)\end{array}$ & $4.7 \times 10^{4}-8.3 \times 10^{5}$ & $\begin{array}{l}2.2 \times 10^{4}-1.4 \times \\
10^{6}\end{array}$ & ND \\
\hline $\begin{array}{l}\text { Fecal streptococci } \\
\text { (CFU/100mL) }\end{array}$ & $110-3.8 \times 10^{5}$ & $170-8100$ & ND \\
\hline
\end{tabular}


Table 3.2 Soil properties

\begin{tabular}{|c|c|}
\hline Parameter (method) & Result \\
\hline $\begin{array}{l}\text { Cation exchange capacity }\left(\mathrm{cmol}^{+} / \mathrm{kg}\right) \\
\mathrm{pH}(\text { water } 1: 1) \\
\text { Buffer } \mathrm{pH} \\
\text { Ca (Mehlich III) (mg/kg dry) }\end{array}$ & $\begin{array}{l}36.4(0.65)^{*} \\
5.3(0.06) \\
6.0(0.0) \\
2662(94)\end{array}$ \\
\hline P (Mehlich III) (mg/kg dry) & $28.6(1.36)$ \\
\hline $\begin{array}{l}\mathrm{Al} \text { (Mehlich III) (mg/kg dry) } \\
\mathrm{K} \text { (Mehlich III) (mg/kg dry) }\end{array}$ & $\begin{array}{l}745(31) \\
77(4.6)\end{array}$ \\
\hline $\begin{array}{l}\text { Mg (Mehlich III) (mg/kg dry) } \\
\text { Organic Matter (\%) } \\
\text { Saturation } \mathrm{P}-\mathrm{P} / \mathrm{Al}(\%) \\
\text { Saturation } \mathrm{Ca}(\%) \\
\text { Saturation } \mathrm{K}(\%) \\
\text { Saturation } \mathrm{Mg}(\%) \\
\text { Saturation } \mathrm{K}+\mathrm{Mg}+\mathrm{Ca}(\%)\end{array}$ & $\begin{array}{l}1224(27) \\
26(2.6) \\
3.8(0.2) \\
36(0.6) \\
0.5(0.06) \\
27.5(0.2) \\
63.9(0.7)\end{array}$ \\
\hline
\end{tabular}

*Standard deviation in parenthesis for $\mathrm{n}=3$

\subsubsection{Methodology}

Over the eight weeks of the experiment, treated and untreated greywater was obtained weekly from the source and characterized for nutrients ( $\mathrm{N}, \mathrm{P}$ and $\mathrm{K}), \mathrm{pH}$, heavy metals and indicator organisms (fecal coliforms and fecal streptococci). In June of 2007, the crops were started in the Macdonald Campus research greenhouse facility of McGill University, Montréal, Canada, following the local growing season of early June to late August. The statistical design consisted of applying one of the three sources of water (3), tap water, untreated greywater or treated greywater, to triplicate pots (3) of each plant type (3), for a total of 27 experimental blocks (Fig. 1). Each block consisted of a 3-gallon Rubbermaid® storage container fitted with drainage holes and runoff trays to avoid crosscontamination. The containers were filled to the brim with potting soil mix and seeded with either lettuce or carrot seeds or planted with pepper seedlings, which 
were thinned after approximately two weeks to yield 3 lettuces/block, 3

peppers/block, and 10 carrots/block. No mechanical shading was used and the greenhouse compartment was programmed to remain under standard local conditions of air temperature and relative humidity. Plants were distributed randomly and watered at the same time each day with $300 \mathrm{~mL}$ of either tap water or one of the two greywater samples $\left(\mathrm{GW}_{\mathrm{u}}\right.$ or $\left.\mathrm{GW}_{\mathrm{t}}\right)$, from seedling stage until full maturity. Watering was performed manually by directly applying the water to the soil surface and avoiding contact of the water with plant surfaces (Fig. 2). Plants were watered five days per week, on the sixth day received no water, and on the seventh day were briefly sprayed with freshwater to simulate periodic rainfall events characteristic of the Montreal region. All blocks were fertilized with the recommended dosage of slow-release fertilizer.

The time span from planting to harvest was $55 \mathrm{~d}$ for lettuce, $65 \mathrm{~d}$ for carrots and $75 \mathrm{~d}$ for peppers. Upon maturity, the edible portion of each plant type was harvested in three successive batches taken on separate days. Sampling portions were aseptically removed from the plant, weighed and transported immediately to the laboratory for testing. In the laboratory, $50 \mathrm{~g}$ samples of each crop/treatment block were cut into small pieces using sterile scissors and immersed in sterilized peptone solution $(0.1 \%)$. The resulting elutions were shaken and tested for fecal coliforms and fecal streptococci according to the method outlined in Collins (2001) for the microbial evaluation of fresh foods. 


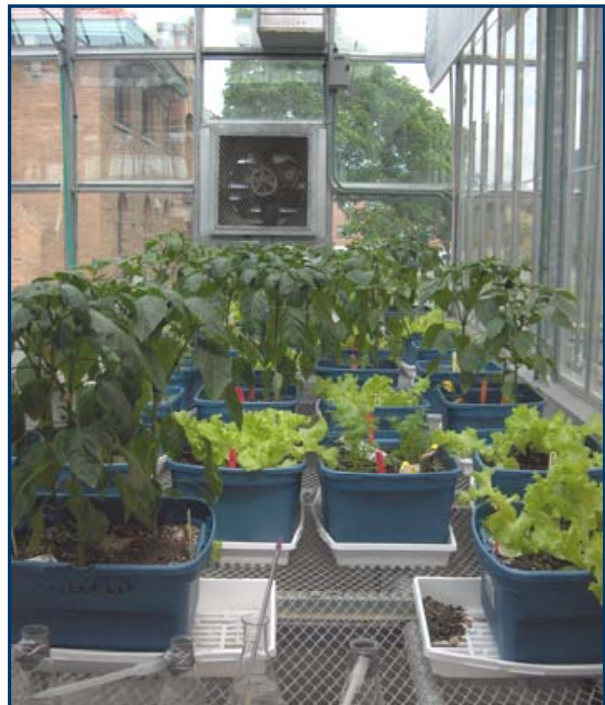

Figure 3.1 Experimental setup

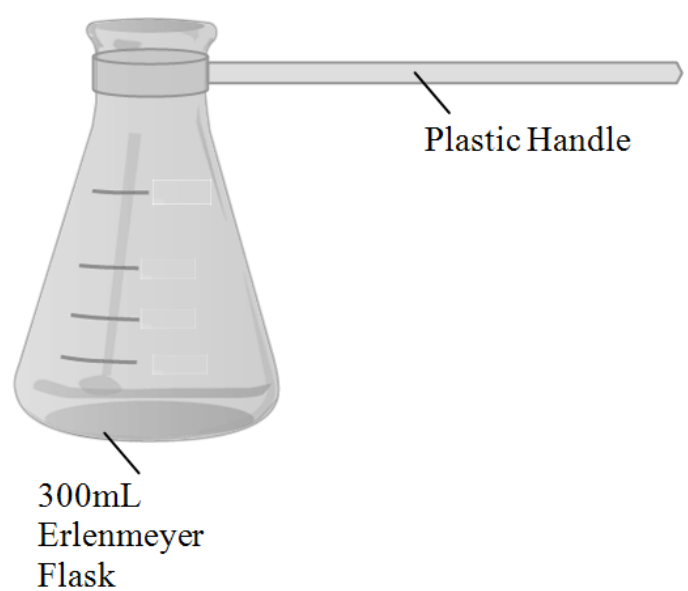

Figure 3.2 Watering device

\subsubsection{Analytical Procedures}

The treated and untreated greywater samples were analyzed using standard methods (APHA 2005). The $\mathrm{pH}$ was measured using with a $\mathrm{pH}$ probe and meter (Corning Model 450, NY, USA). The COD was determined by colorimetry after reacting $2 \mathrm{~mL}$ of sample with potassium dichromate at $150^{\circ} \mathrm{C}$ for $1 \mathrm{~h}$. Total solids were determined by drying for $24 \mathrm{~h}$ at $70^{\circ} \mathrm{C}$ (VWR, Sheldon Manufacturing Inc., Model No. 1327F, Cornelius, OR, USA). Metals and trace elements (Al, Ca, Cd, Co, $\mathrm{Cr}, \mathrm{Cu}, \mathrm{Fe}, \mathrm{K}, \mathrm{Mg}, \mathrm{Mn}, \mathrm{Mo}, \mathrm{Na}, \mathrm{P}, \mathrm{Pb}, \mathrm{S}, \mathrm{Zn}$ ) were determined by Inductively Coupled Plasma Mass Spectrometry (ICP-MS, Agilent, Santa Clara, CA, USA). Ammonia nitrogen was determined using an Ammonia-sensitive probe (Orion, Boston, MA, USA) connected to the $\mathrm{pH} /$ ion meter. The phosphorous and potassium levels were obtained by colorimetry based on the Amino acid method (P) and Tetraphenylborate method (K) and by means of a spectrophotometer (Hach DR 2800, Type LPG, Loveland, CO, USA). 
Both bacterial groups were quantified using the membrane filtration technique. Fecal coliforms were incubated on mFC agar (Difco, Franklin Lakes, NY, US) at $44.5^{\circ} \mathrm{C}$ for $24 \mathrm{~h}$, while fecal streptococci were cultured on KF Streptococcus agar (Difco, Franklin Lakes, NY, US) at $35^{\circ} \mathrm{C}$ for 44 to $48 \mathrm{~h}$. The peptone solutions $(0.1 \%)$ used to soak the portions of edible crops were tested for fecal coliforms and fecal streptococci according to the method outlined in Collins (2001) for the testing of fresh foods. Samples of 50g from each crop were also dried for $24 \mathrm{~h}$ at $70{ }^{\circ} \mathrm{C}$ to measure dry mass and establish the total mature crop mass. Crop heavy metal content was not measured because of insignificant concentrations in the greywaters.

\subsubsection{Statistical analysis}

The difference in population of indicator bacteria on crop surfaces was compared by single-factor ANOVA to determine the effect of irrigation water on each crop. Crop type and water quality were also compiled in a two-way ANOVA to gauge the effect of plant type on the likelihood of contamination with indicator bacteria (Berthouex and Brown 2002).

\subsection{Results and Discussion}

\subsubsection{Greywater characteristics}

In most respects, the experimental greywater was similar to that reported in other greywater characterization studies (Table 3). Nutrients important for plant growth, namely $\mathrm{N}, \mathrm{P}$, and $\mathrm{K}$, were detected in minor quantities of $1.2-6.2,0.24$ 1.02 and $2.2-2.5 \mathrm{mg} / \mathrm{L}$, respectively. Comparatively low P levels in this study can 
largely be attributed to the use of phosphate-free soaps and detergents within the household. Greywater $\mathrm{N}$ detected mainly as $\mathrm{NH}_{4}+-\mathrm{N}$, was expected to be low due to the small absolute quantities of fecal matter present in greywater. Solids and COD levels of $313-543$ and $278-435 \mathrm{mg} / \mathrm{L}$ are indicative of a low-to-medium grade wastewater (Jefferson et al. 2004). Micro-minerals namely calcium, magnesium and sodium were detected in quantities of $30-44,8.0$ - 9.9 and $20-27 \mathrm{mg} / \mathrm{L}$, respectively. Sulfur was present at levels of $5-8.8 \mathrm{mg} / \mathrm{L}$. Heavy metals were not present in any detectable amount.

Fecal coliform and fecal streptococcus counts varied widely from week to week, from $2.2 \times 10^{4}-1.4 \times 10^{6} \mathrm{CFU} / 100 \mathrm{~mL}$ and $113-8100 \mathrm{CFU} / 100 \mathrm{~mL}$, respectively (Fig. 3). Fecal bacteria counts were slightly higher than those previously reported, possibly due to the presence of a young child in the household (Rose et al. 1991).

Control samples showed Montreal tap water to contain $9.6 \mathrm{mg} / \mathrm{L} \mathrm{Ca}, 2.1 \mathrm{mg} / \mathrm{L}$ $\mathrm{Mg}$, and $18.7 \mathrm{mg} / \mathrm{L} \mathrm{Na}$. Elevated $\mathrm{Ca}$ and $\mathrm{Mg}$ levels in the greywater could therefore be associated with a buildup of 'hard' water deposits in pipes, fixtures, and the treatment system itself.

The untreated and treated greywater samples $\left(\mathrm{GW}_{\mathrm{u}}\right.$ and $\left.\mathrm{GW}_{\mathrm{t}}\right)$ were not significantly different for all parameters tested, suggesting that the treatment was ineffective and its effect can be ignored. For the purposes of statistically analyzing the data, the results obtained with $\mathrm{GW}_{\mathrm{u}}$ and $\mathrm{GW}_{\mathrm{t}}$ were combined. 
Table 3.3 Greywater characteristics from this and other characterization studies

\begin{tabular}{|c|c|c|c|c|}
\hline \multirow[t]{3}{*}{ Parameter } & $\begin{array}{l}\text { Experimental } \\
\text { Greywater }^{\text {a }}\end{array}$ & $\begin{array}{l}\text { Christova- } \\
\text { Boal et al. } \\
\text { (1996) }\end{array}$ & $\begin{array}{l}\text { Friedler } \\
(2004)\end{array}$ & $\begin{array}{l}\text { Surendran } \\
\text { and } \\
\text { Wheatley } \\
(1998)\end{array}$ \\
\hline & Canada & Australia & Israel & UK \\
\hline & $\begin{array}{l}\text { Shower and } \\
\text { Laundry }\end{array}$ & $\begin{array}{l}\text { Bathroom } \\
\text { and Laundry }\end{array}$ & $\begin{array}{l}\text { Shower and } \\
\text { Laundry }\end{array}$ & $\begin{array}{l}\text { Shower and } \\
\text { Laundry }\end{array}$ \\
\hline $\mathrm{pH}$ & $6.7-7.9$ & $6.4-10$ & $7.4-7.5$ & $7.6-8.1$ \\
\hline TS (mg/L) & $313-633$ & $\mathrm{NT}^{\mathrm{b}}$ & $\begin{array}{l}1090- \\
2021\end{array}$ & $631-658$ \\
\hline $\mathrm{COD}(\mathrm{mg} / \mathrm{L})$ & $161-435$ & NT & $319-996$ & $424-725$ \\
\hline $\mathrm{NH}_{4}^{+}-\mathrm{N}(\mathrm{mg} / \mathrm{L})$ & $1.2-6.2$ & $<0.1-15$ & $1.2-4.9$ & $1.56-10.7$ \\
\hline $\mathrm{P}(\mathrm{mg} / \mathrm{L})$ & $0.24-1.21$ & $0.062-42$ & $3.3-55.0$ & $1.63-101$ \\
\hline $\mathrm{K}(\mathrm{mg} / \mathrm{L})$ & $0.6-4.4$ & NT & NT & NT \\
\hline $\mathrm{Al}(\mathrm{mg} / \mathrm{L})$ & $\mathrm{ND}^{\mathrm{c}}$ & $<1.0-21$ & NT & NT \\
\hline $\mathrm{Ca}(\mathrm{mg} / \mathrm{L})$ & $28-44$ & $3.5-12$ & NT & NT \\
\hline $\mathrm{Cd}(\mathrm{mg} / \mathrm{L})$ & ND & $<0.001$ & NT & $<0.001$ \\
\hline Co $(\mathrm{mg} / \mathrm{L})$ & ND & NT & NT & NT \\
\hline $\mathrm{Cr}(\mathrm{mg} / \mathrm{L})$ & ND & NT & NT & NT \\
\hline $\mathrm{Cu}(\mathrm{mg} / \mathrm{L})$ & ND & $<0.05-0.27$ & NT & $0.11-0.32$ \\
\hline $\mathrm{Mg}(\mathrm{mg} / \mathrm{L})$ & $8.0-10.1$ & $1.1-2.9$ & NT & NT \\
\hline $\mathrm{Mn}(\mathrm{mg} / \mathrm{L})$ & ND & NT & NT & NT \\
\hline Mo (mg/L) & ND & NT & NT & NT \\
\hline $\mathrm{Na}(\mathrm{mg} / \mathrm{L})$ & $18-27$ & $7.4-480$ & $151-530$ & NT \\
\hline $\mathrm{Pb}(\mathrm{mg} / \mathrm{L})$ & ND & NT & NT & $0.003-0.03$ \\
\hline $\mathrm{S}(\mathrm{mg} / \mathrm{L})$ & $3.3-8.8$ & $1.2-40$ & NT & NT \\
\hline $\mathrm{Fe}(\mathrm{mg} / \mathrm{L})$ & $0.1-0.45$ & $0.29-1.1$ & NT & NT \\
\hline Zn (mg/L) & $0.01-0.42$ & $0.09-6.3$ & NT & $0.059-0.31$ \\
\hline SAR & $3.9-6.1$ & NT & NT & NT \\
\hline $\begin{array}{l}\text { Fecal coliform } \\
\left(\mathrm{CFU}^{\mathrm{d} / 100 \mathrm{~mL})}\right.\end{array}$ & $\begin{array}{l}2.2 \times 10^{4}-1.4 \\
\times 10^{6}\end{array}$ & $\begin{array}{l}110-3.3 \times \\
10^{3}\end{array}$ & $4 \times 10^{6}$ & $600-728$ \\
\hline $\begin{array}{l}\text { Fecal streptococci } \\
(\mathrm{CFU} / 100 \mathrm{~mL})\end{array}$ & $113-8100$ & $23-2.4 \times 10^{3}$ & NT & NT \\
\hline
\end{tabular}

${ }^{\mathrm{a}}$ Combined $\mathrm{GW}_{\mathrm{u}}$ and $\mathrm{GW}_{\mathrm{t}}$ results

${ }^{\mathrm{b}} \mathrm{NT}=$ Not tested;

${ }^{\mathrm{c}} \mathrm{ND}=$ None detected;

${ }^{\mathrm{d}} \mathrm{CFU}=$ Colony Forming Unit 


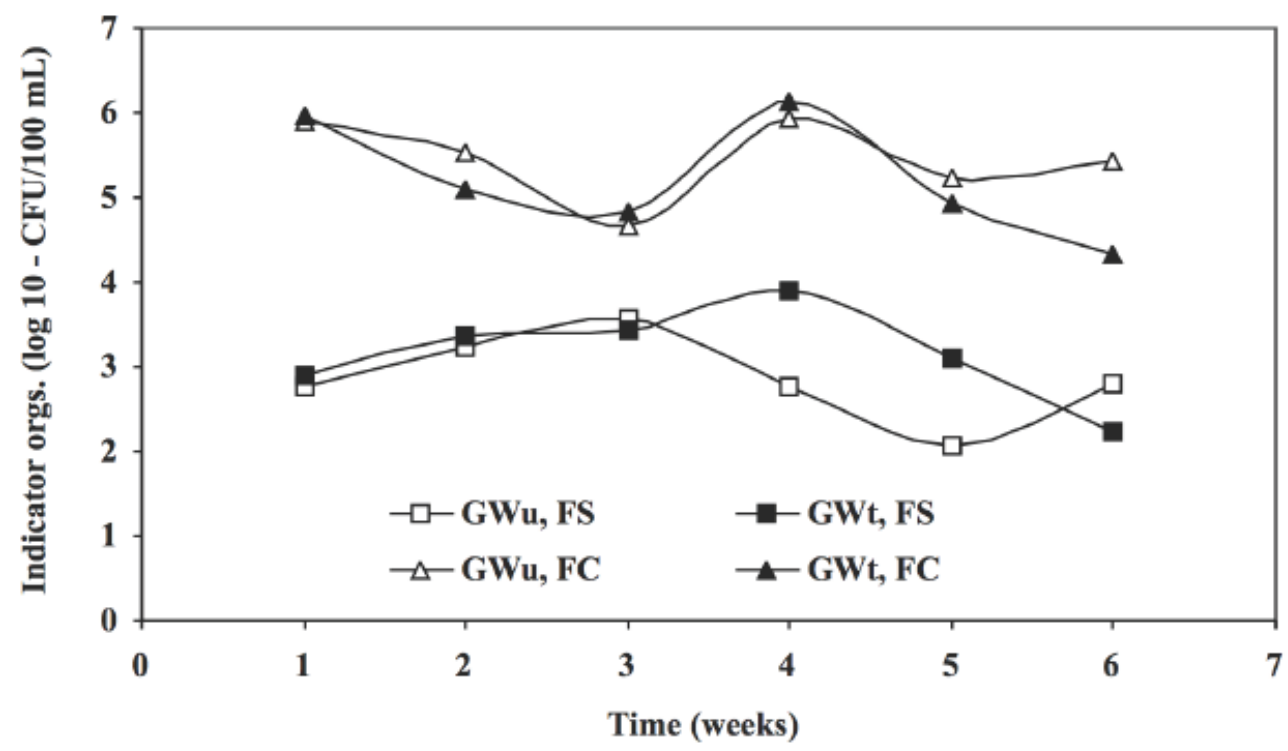

Figure 3.3 Average indicator organism counts for the untreated greywater $\left(\mathrm{GW}_{\mathrm{u}}\right)$ and the treated greywater $\left(\mathrm{GW}_{\mathrm{t}}\right)$ over the six week sampling period, where $\mathrm{FC}$ is fecal coliforms and FS is fecal streptococci.

\subsubsection{Irrigation effects}

In terms of crop dry weight per experimental block, no significant difference was observed between that irrigated with greywater and that receiving regular tap water (results not shown). This result is explained by the low nutrient content of the greywaters, as well as their low and therefore un-inhibitive levels of heavy metals. All plants grew well and produced healthy fruit, with only one lettuce control block suffering from pest-related weakness.

Fecal coliforms were detected in low numbers on lettuce leaves and carrot surfaces, and not at all on the surface of peppers (Fig. 4). For all crops, there was no statistical difference $(\alpha=0.05)$ in fecal coliform levels on crop surfaces between the tap water and greywater treatment groups. The highest fecal coliform counts were found on carrots, which is expected because the edible portion is in direct contact with the soil and irrigation water. Surprisingly, control blocks on average showed 
higher but not statistically different fecal coliform counts than greywater-irrigated blocks. The high variation of the results, however, indicates that the data is part of a completely randomly distributed result and not as an indicator of higher contamination levels on tap water-irrigated crops.

Fecal streptococcus counts displayed a different distribution than those of fecal coliform. These were detected on all plant surfaces, with the highest contamination discovered on lettuce leaves. Fecal Streptococcus levels were slightly higher on greywater-irrigated lettuce and peppers, and lower on carrots than the tap water-irrigated crops. Again, the difference between treatments was not significant for any of the crops tested $(\alpha=0.05)$. Although water tests with KF streptococcus agar showed the growth of only one type of bacteria, food tests on the same media plates had a more varied appearance. To ensure that the study was focused on the same Streptococci detected in the greywater, only small red colonies were counted for both the food waste and the greywaters (Hall et al. 1963). In two-way ANOVA analysis, the crop type was found to be significant for the prevalence of both indicator bacteria $(\alpha=0.05)$. Fecal coliforms were more likely to be present on carrots and fecal streptococci more likely present on lettuce.

The low levels of indicator bacteria detected on the food crops despite high numbers in greywater samples may indicate some buffering effect of the soil biotic community or signal the insufficiency of chosen indicator bacteria to signal crop contamination by waterborne pathogens. The movement of each pathogenic organism on plant surfaces and into plant tissues will naturally be species-specific and may be difficult to predict with the same methodology employed for water quality testing. 
a)

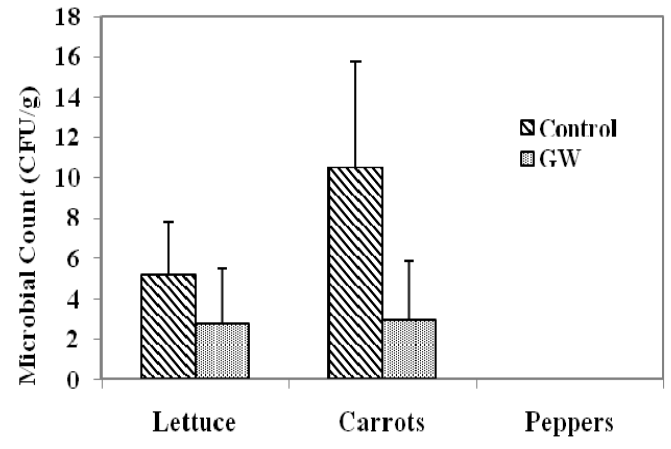

b)

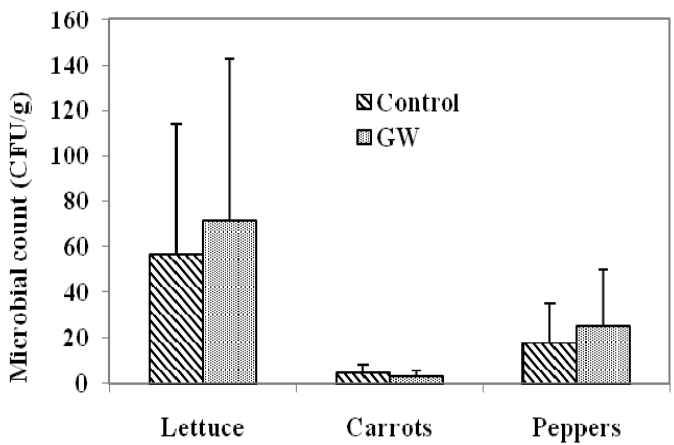

Figure 3.4 Crop microbial counts for (a) fecal coliforms and (b) fecal streptococci, where the bar indicates the standard deviation. The control treatment used tap water while the other treatment used greywater $(\mathrm{GW})$. Since both the untreated greywater $\left(\mathrm{GW}_{\mathrm{u}}\right)$ and the treated greywater $\left(\mathrm{GW}_{\mathrm{t}}\right)$ were not statistically different in microbial count, their results were pooled.

The relative absence of fecal streptococcus bacteria from carrot surfaces and their prevalence on aboveground crops is indeed noteworthy as it runs contrary to conventional logic concerning crop contamination. This may indicate some degree of contamination of aboveground plants by airborne streptococci from other sources, or the adept movement of bacteria from the soil to the crevice-filled leaves of young lettuce plants. Fecal coliform results more closely mirror expectations for bacterial transmission by contaminated irrigation water. Further, this group encompasses the Escherichia Coli species, some strains of which are foodborne pathogens known to be responsible for outbreaks of illness in humans. For these reasons, fecal coliforms, or more specifically E.Coli, may be most appropriate for use as indicator organisms in future research of this type. Confirmation of appropriate indicators is important to efficiently investigate the real risk associated with irrigating food crops with faecally contaminated waters of all types.

The randomly distributed bacterial results of this study echo previous research wherein other greywater streams (Jackson et al. 2006), sludge applications (Ibiebele 
and Inyang 1986) and full wastewater (Sadovski et al. 1978) were not found to increase crop contamination when contact was avoided. This is significant because it opens the door for the exploration of alternative non-potable sources for irrigation water requirements. More factors need to be investigated, including bacterial survival and accumulation in the soil, transmission of viruses and parasites, and survival of organisms into drainage or groundwater, to fully investigate the use of domestic greywater for irrigation purposes.

\subsection{Risk analysis}

The real risk associated with the consumption of crops irrigated with greywater is difficult to evaluate because of a lack of published microbiological standards for fresh produce and some uncertainty related to the effectiveness of indicator organisms to signal the presence of pathogens on food. In its 1986 publication, the International Commission on Microbiological Specifications for Foods (ICMSF) suggested a limit of $100 \mathrm{CFU} / \mathrm{g}$ for E.Coli on fruits and vegetables, with a sample size (n) of at least five (5) and with no two (2) samples exceeding that limit in any one testing period. Since E. Coli is incorporated into the fecal coliform category, this risk analysis can be translated into a conservative limit of $100 \mathrm{CFU} / \mathrm{g}$ for fecal coliforms. Crop results from this study did not exceed this level, nor was any one sample found to exceed it.

There is no established standard for enterococci levels on foods, and the real danger of their presence is subject to debate. Fecal streptococci are naturallyoccurring in some foods, most notably meats and cheeses, and their relationship to other pathogenic organisms in that setting is unclear (Franz et al. 1999). 
A basic risk analysis can however be performed using the data from Fig. 4 and assuming that the greywater will be used to irrigate a rooftop garden in Montreal, Canada. Data for probability of infection and likeliness of illness per incidence of infection is based on Hurst (2002) who provides overall values for enteric pathogenic bacteria. The risk analyses presented in Tables 4 and 5 assume that the vegetable crops will be consumed at an estimated rate of one $40 \mathrm{~g}$ serving/day (approx. one pepper, three carrots or six lettuce leaves), every other day, over a three-month harvest period, based on the short growing season and single yearly harvest characteristic of Montreal gardens. Because indicator bacteria were also recovered from control blocks watered with municipal tap water, greywater data are also presented in terms of increased, and in some cases, decreased risk when compared to the consumption of tap water-irrigated crops. Results show no clear trend in the risk associated with consuming greywater-irrigated crops. This indicates a random result and suggests that further research is needed. 
Table 3.4 Risk assessment based on fecal coliform counts

\begin{tabular}{|c|c|c|c|c|c|c|}
\hline & $\begin{array}{l}\text { Lettuce- } \\
\text { tap water }\end{array}$ & $\begin{array}{l}\text { Lettuce- } \\
\text { greywater }\end{array}$ & $\begin{array}{l}\text { Carrot- } \\
\text { tap water }\end{array}$ & $\begin{array}{l}\text { Carrot- } \\
\text { greywater }\end{array}$ & $\begin{array}{l}\text { Pepper- } \\
\text { tap water }\end{array}$ & $\begin{array}{l}\text { Pepper- } \\
\text { greywater }\end{array}$ \\
\hline $\begin{array}{l}\text { Bacteria }\left(\mathrm{CFU}^{\mathrm{a}} \text { /gram of }\right. \\
\text { crop) }\end{array}$ & 5.21 & 2.76 & 10.52 & 2.93 & 0 & 0 \\
\hline Mass ingested $(\mathrm{g} / \mathrm{d})$ & 40 & 40 & 40 & 40 & 40 & 40 \\
\hline Ingestion frequency $(\mathrm{d} / \mathrm{y})$ & 45 & 45 & 45 & 45 & 45 & 45 \\
\hline Probability of infection ${ }^{\mathrm{b}}$ & 0.00001 & 0.00001 & 0.00001 & 0.00001 & 0.00001 & 0.00001 \\
\hline Probability of illness ${ }^{\mathrm{b}}$ & 0.49 & 0.49 & 0.49 & 0.49 & 0.49 & 0.49 \\
\hline $\begin{array}{l}\text { Estimated annual risk of } \\
\text { illness }\end{array}$ & 0.046 & 0.024 & 0.093 & 0.026 & 0 & 0 \\
\hline Comparative risk & & $\begin{array}{l}47 \% \text { lower } \\
\text { than tap } \\
\text { water }\end{array}$ & & $\begin{array}{l}72 \% \text { lower } \\
\text { than tap } \\
\text { water }\end{array}$ & & N/A \\
\hline
\end{tabular}

${ }^{\mathrm{a}} \mathrm{CFU}=$ Colony Forming Unit

${ }^{\mathrm{b}}$ Source $=$ Hurst et al. 2002

Table 3.5 Risk assessment based on fecal streptococcus counts

\begin{tabular}{|c|c|c|c|c|c|c|}
\hline & $\begin{array}{l}\text { Lettuce- } \\
\text { tap water }\end{array}$ & $\begin{array}{l}\text { Lettuce- } \\
\text { greywater }\end{array}$ & $\begin{array}{l}\text { Carrot- } \\
\text { tap water }\end{array}$ & $\begin{array}{l}\text { Carrot- } \\
\text { greywater }\end{array}$ & $\begin{array}{l}\text { Pepper- } \\
\text { tap water }\end{array}$ & $\begin{array}{l}\text { Pepper- } \\
\text { greywater }\end{array}$ \\
\hline $\begin{array}{l}\text { Bacteria }\left(\mathrm{CFU}^{\mathrm{a}} / \text { gram of }\right. \\
\text { crop) }\end{array}$ & 56.83 & 71.52 & 4.13 & 2.85 & 17.60 & 24.87 \\
\hline Mass ingested (g/d) & 40 & 40 & 40 & 40 & 40 & 40 \\
\hline Ingestion frequency $(\mathrm{d} / \mathrm{y})$ & 45 & 45 & 45 & 45 & 45 & 45 \\
\hline Probability of infection ${ }^{\mathrm{b}}$ & 0.00001 & 0.00001 & 0.00001 & 0.00001 & 0.00001 & 0.00001 \\
\hline Probability of illness ${ }^{\mathrm{b}}$ & 0.49 & 0.49 & 0.49 & 0.49 & 0.49 & 0.49 \\
\hline $\begin{array}{l}\text { Estimated annual risk of } \\
\text { illness }\end{array}$ & 0.501 & 0.631 & 0.036 & 0.025 & 0.155 & 0.219 \\
\hline Comparative risk & & $\begin{array}{l}20 \% \\
\text { higher than } \\
\text { tap water }\end{array}$ & & $\begin{array}{l}31 \% \text { lower } \\
\text { than tap } \\
\text { water }\end{array}$ & & $\begin{array}{l}41 \% \\
\text { higher than } \\
\text { tap water }\end{array}$ \\
\hline
\end{tabular}

${ }^{\mathrm{a}} \mathrm{CFU}=$ Colony Forming Unit

${ }^{\mathrm{b}}$ Source $=$ Hurst et al. 2002

\subsection{Conclusion}

The objective of this project was to evaluate the impact of irrigating vegetable crops with household greywater which, despite its exclusion of toilet wastes, can still be highly polluted and exceeds international microbial safety standards for unlimited food crop irrigation (WHO 2006). The greywater used in this study was found to contain very low levels of N, P, K and heavy metals. However, high levels of 
indicator bacteria suggest the presence of pathogenic organisms in the greywater, which can pose a real health risk to humans that come into contact with it. Results from this study suggest that use of household greywater for irrigation does not necessarily directly correlate to higher levels of bacterial contamination of food crops when soil-level irrigation is employed. Although the same indicator bacteria present in the greywater were detected on crop surfaces, their numbers were not significantly higher than those found on control crops irrigated with normal tap water. More research is needed in the area of pathogen enumeration on crop surfaces so that easy detection methods, sampling regimes, and acceptable contamination limits can be agreed upon.

The key result in this study was the similarity in the distributions of bacteria on plant surfaces following irrigation with tap and domestic greywater. Both results showed very high variation. This suggests that bacterial contamination may not be a significant risk factor for edible crop irrigation with faecally polluted water, with the provision that plants are not sprayed or otherwise allowed to come into direct contact with contaminated water. The true safety of these practices must be addressed as part of the effort to reconcile food production water needs in an era where freshwater supplies are increasingly limited and difficult to access. 


\subsection{References}

American Public Health Association, American Water Works Association, Water Environment Federation. (1998). Standard methods for the examination of water and wastewater. 20th ed., Washington, DC: APHA.

Armon, R., Dosoretz, C.G., Azov, Y., Shelef, G. (1994). Residual contamination of crops irrigated with effluent of different qualities: a field study. Water Science And Technology, 30(9), 239-248.

Berthouex, P.M., Brown, L.C. (2002). Statistics for environmental engineers. 2nd ed., New York, NY: Lewis Publishers.

Brandes, M. (1978). Characteristics of effluents from separate septic tanks treating grey water and black water from the same house. Journal Water Pollution Control Federation, 50(11), 2547-2559.

Casanova, L.M., Gerba, C.P., Karpiscak, M. (2001). Chemical and microbial characterization of household graywater. Journal Of Environmental Science And Health Part A-Toxic/Hazardous Substances \& Environmental Engineering, 36(4), 395-401

Christova-Boal, D., Eden, R.E., McFarlane, S. (1996). An investigation into greywater reuse for urban residential properties. Desalination, 106, 391-397.

Collins, C.H. (2004). Collins and Lyne's microbiological methods. 8th ed., New York, NY: Arnold.

Eriksson, E., Auffarth, K., Henze, M., Ledin, A. (2002). Characteristics of grey wastewater. Urban Water, 4, 85-104.

Franz, C.M.A.P., Holzapfel, W.H., Stiles, M.E. (1999). Enterococci at the crossroads of food safety? International Journal of Food Microbiology, 47, 1-24.

Friedler, E. (2004). Quality of individual domestic greywater streams and its implication for on-site treatment and reuse possibilities. Environmental Technology, 25, 997-1008.

Gerba, C.P., Smith, J.E. (2005). Sources of pathogenic microorganisms and their fate during land application of wastes. Journal Of Environmental Quality, 34, 4248.

Hall, H.E., Brown, D.F., Angelotti, R. (1963). The Recovery of Enterococci from Food Using KF Streptococcus Media. Journal of Food Science, 28(5), 566571.

Hurst, C.J. (2002). Estimating the risk of infectious disease associated with pathogens in water. In Hurst, C.J., Crawford, R.L., Knudson, G.R., McInerney, M.J. and Stetzenbach, L.D. (eds.), Manual of Environmental Microbiology (2nd edn.), pp.309-319. Washington, DC: ASM Press.

Ibiebele, D.D., \& Inyang, A.D. (1986). Environmental movement of indicator bacteria from soil amended with undigested sewage sludge. Environmental Pollution (Series A), 40, 53-62.

International Commission on Microbiological Specifications for Foods. (1986). Micro-organisms in foods 2: Sampling for microbiological analysis: Principles and specific applications. Toronto, ON: University of Toronto Press.

Jackson, S., Rodda, N., Salukazana, L. (2006). Microbiological assessment of food crops irrigated with domestic greywater. Water SA, 32(5), 700-704. 
Jefferson, B., Palmer, A., Jeffrey, P., Stuetz, R., Judd, S. (2004). Grey water characterisation and its impact on the selection and operation of technologies for urban reuse. Water Science \& Technology, 50(2), 157-164.

Madungwe, E. and Sakuringwa, S. (2007). Greywater reuse: A strategy for water demand management in Harare? Physics and Chemistry of the Earth, 32(1518), 1231-1236.

Mills, R.G., Bartlett C.L., Kessel, J.F. (1925). The penetration of fruits and vegetables by bacteria and other particulate matter, and the resistance of bacteria, protozoan cysts and helminth ova to common disinfection methods. American Journal of Epidemiology, 5(5), 559-579.

Ottosson, J. (2003). Hygiene aspects of greywater and greywater reuse. Royal Institute of technology (KTH)/Swedish Institute for Infectious Disease Control (SMI), Stockholm: Licentiate Thesis.

Ottosson, J. (2005). Comparative Analysis of Pathogen Occurrence in WastewaterManagement strategies for barrier function and microbial control. Royal Institute of technology (KTH)/Swedish Institute for Infectious Disease Control (SMI), Stockholm: Doctorate Thesis.

Roesner, L., Qian, Y., Criswell, M., Stromberger, M., Klein, S. (1994). Long-Term Effects of Landscape Irrigation Using Household Graywater- Literature Review and Synthesis. Resource Document. Water Environment Research Foundation. http://www.cleaning101.com/files/SDA WERF_Graywater_2006.pdf. Accessed 20 January 2007

Rose, J.B. (1991). Microbial quality and persistence of enteric pathogens in graywater from various household sources. Water Research, 25(1), 37-42.

Sadovski, A.Y., Fattal, B., Goldberg, D., Katzenelson, E. (1978). High levels of microbial contamination of vegetables irrigated with wastewater by the drip method. Applied and Environmental Microbiology, 36(6), 824-830.

Surendran, S., Wheatley, A.D. (1998). Grey-water reclamation for non-potable reuse. Journal of the Chartered Institution of Water and Environmental Management, 12, 406-413.

Toze, S. (2006). Reuse of effluent water-benefits and risks. Agricultural Water Management, 80, 147-159.

World Health Organization. (2006). Guidelines for the safe use of wastewater, excreta and greywater. Resource document. WHO.

$\mathrm{http}: / /$ www.who.int/water_sanitation_health/

wastewater/gsuww/en/index.html. Accessed 5 March 2007. 


\section{SUMMARY AND DIRECTIONS FOR FUTURE RESEARCH}

The responsible management of water resources will become one of the main challenges of the $21^{\text {st }}$ century. It will necessitate a concerted effort to both limit our draws on natural water bodies and control the quality of effluents sent back into the environment. Water reuse of all forms should be encouraged as it allows the maximization of water's utility on-site and encourages the treatment of used water prior to discharge. Greywater reuse at the domestic level may well be the simplest form of water reuse and should be investigated as a means to reduce the impact of residential developments on water resources worldwide.

Though it excludes toilet wastes and has a low nutrient content, domestic greywater can indeed be highly biologically polluted. High counts of indicator bacteria associated with fecal pollution in greywater studies have been attributed by default to the washing activities that contribute to greywater streams, but their exact source should be investigated. The greywater analyzed in this study contained no heavy metals, but elevated levels of indicator organisms pointed to a strong concentration of pathogenic organisms. Fecal coliform counts in the greywater exceeded WHO (2006) water quality standards for unrestricted food crop irrigation by a factor of 10-100. In food tests, however, the contamination of crops by this bacteria-rich irrigation water was not evident. Concentrations of indicator bacteria on food surfaces were low and did were not correlated with water quality data. Although the same indicator bacteria present in the greywater were detected on crop surfaces, their numbers were not significantly higher than those found on control crops irrigated with normal tapwater. This may indicate some buffering effect of the soil biotic community or signal the insufficiency of chosen indicator bacteria to 
measure crop contamination by waterborne pathogens. The movement of each pathogenic organism on plant surfaces and into plant tissues will naturally be speciesspecific and may be difficult to predict with the same methodology employed for water quality testing. More research is needed in the area of pathogen enumeration on crop surfaces so that easy detection methods, sampling regimes, and acceptable contamination limits can be agreed upon. Confirmation of appropriate indicators is also important in order to efficiently investigate the real risk associated with irrigating food crops with faecally contaminated waters of all types.

The key result in this study was the similarity in the distributions of bacteria on plant surfaces following irrigation with tap and domestic greywater. Both results showed very high variation. This suggests that bacterial contamination may not be a important risk factor for edible crop irrigation with faecally polluted water, with the provision that plants are not sprayed or otherwise allowed to come into direct contact with contaminated water. This result mirrors previous research wherein other greywater streams (Jackson et al. 2006), sludge applications (Ibiebele and Inyang, 1986) and full wastewater (Sadovski et al. 1978) were not found to increase crop contamination when contact was avoided. It is significant because it opens the door for the exploration of alternative non-potable sources for irrigation water requirements. More factors need to be investigated, including bacterial survival and accumulation in the soil, transmission of viruses and parasites, and survival of organisms into drainage or groundwaters, in order to fully investigate the use of faecally polluted greywater for irrigation purposes. The true safety of these practices must be addressed as part of the effort to reconcile food production water needs in an era where freshwater supplies are increasingly limited and difficult to access. 


\subsection{References}

Ibiebele, D.D., \& Inyang, A.D. (1986). Environmental movement of indicator bacteria from soil amended with undigested sewage sludge. Environmental Pollution (Series A), 40, 53-62.

Jackson, S., Rodda, N., Salukazana, L. (2006). Microbiological assessment of food crops irrigated with domestic greywater. Water SA, 32(5), 700-704.

Sadovski, A.Y., Fattal, B., Goldberg, D., Katzenelson, E. (1978). High levels of microbial contamination of vegetables irrigated with wastewater by the drip method. Applied and Environmental Microbiology, 36(6), 824-830.

World Health Organization (WHO). (2006). Guidelines for the safe use of wastewater, excreta and greywater. Resource document. WHO.

http://www.who.int/water_sanitation_health/wastewater/gsuww/en/index.html. Accessed 5 March 2007. 


\section{COMPLETE LISTING OF REFERENCES}

Al-Ghazali, M.R., Al-Azawi, S.K. (1990). Listeria monocytogenes contamination of crops grown on soil treated with sewage sludge cake. Journal of Applied Bacteriology, 69, 642-647.

American Public Health Association, American Water Works Association, Water Environment Federation. (1998). Standard methods for the examination of water and wastewater. $20^{\text {th }}$ ed., Washington, DC: APHA.

Armon, R., Dosoretz, C.G., Azov, Y., Shelef, G. (1994). Residual contamination of crops irrigated with effluent of different qualities: a field study. Water Science And Technology, 30(9), 239-248.

Berthouex, P.M., \& Brown, L.C. (2002). Statistics for environmental engineers. $2^{\text {nd }}$ ed., New York, NY: Lewis Publishers.

Birks, R., \& Hills, S. (2007). Characterisation of Indicator Organisms and Pathogens in Domestic Greywater for Recycling. Environmental Monitoring and Assessment, 129(1-3), 61-69.

Brandes, M. (1978). Characteristics of effluents from separate septic tanks treating grey water and black water from the same house. Journal Water Pollution Control Federation, 50(11), 2547-2559.

Casanova, L.M., Gerba, C.P., Karpiscak, M. (2001). Chemical and microbial characterization of household graywater. Journal Of Environmental Science And Health Part A-Toxic/Hazardous Substances \& Environmental Engineering, 36(4), 395-401

Christova-Boal, D., Eden, R.E., McFarlane, S. (1996). An investigation into greywater reuse for urban residential properties. Desalination, 106, 391-397.

Collins, C.H. (2004). Collins and Lyne's microbiological methods. $8^{\text {th }}$ ed., New York, NY: Arnold.

Carr, R. M., Blumenthal, U.J., Mara, D. D. (2004). Guidelines for the safe use of wastewater in agriculture: revisiting WHO guidelines. Water Science and Technology, 50(2), 31-38.

Chang, A.C., Pan, G., Page, A.L., Asano, T. (2001). Developing Human Health-related Chemical Guidelines for Reclaimed Waster and Sewage Sludge Applications in Agriculture. Resource Document. World Health Organization. http://www.who.int/ water_sanitation_health/wastewater/gwwuchemicals.pdf. Accessed February 20, 2007.

Choi, C., Song, I., Stine, S., Pimentel J., Gerba, C. (2004). Role of irrigation and wastewater reuse: comparison of subsurface irrigation and furrow irrigation. Water Science and Technology, 50(2), 7.

De Roever, C. (1998). Microbiological Safety Evaluations and Recommendations on Fresh Produce. Food Control, 9(6), 321-347.

Diaper, C., \& Sharma, A. (2007). Innovative sewerage solutions for small rural towns. Water Science \& Technology, 56 (5), 97-103.

Dixon, A., Butler, D., Fewkes, A., Robinson, M. (2000). Measurement and modelling of quality changes in stored untreated grey water. Urban Water, 1, 293-306.

Environment Canada (2001). Freshwater Facts for Canada and the World. Resource Document. Government of Canada http://www.ec.gc.ca/water/en/info /facts/e_contnt.htm. Accessed 12 February 2007

Enriquez, C., Alum, A., Suarez-Rey, E.M., Choi, C.Y., Oron, G., Gerba, C.P. (2003). Bacteriophages MS2 and PRD1 in turfgrass by subsurface drip irrigation. Journal of 
Environmental Engineering-ASCE, 129(9), 852-857.

Eriksson, E., Auffarth, K., Henze, M., Ledin, A. (2002). Characteristics of grey wastewater. Urban Water, 4, 85-104.

Exall, K., Marsalek, J., Schaefer, K. (2004). A Review of Water Reuse and Recycling, with Reference to Canadian Practice and Potential: 1. Incentives and Implementation. Water Quality Research Journal of Canada, 39(1), 1-12.

Exall, K. (2004). A review of water reuse and recycling, with reference to Canadian practice and potential: 2. Applications. Water Quality Research Journal of Canada, 39(1), 13-28.

Fane, S. A., Ashbolt, N. J., White, S. B. (2002). Decentralised urban water reuse: The implications of system scale for cost \& pathogen risk. Water Science and Technology, 46(6-7), 281-288.

Filip, Z., Kanazawa, S., Berthelin, J. (2000). Distribution of Microorganisms, Biomass ATP, and Enzyme activities in Organic and Mineral Particles of a Long-Term Wastewater Irrigated Soil. Journal of Plant Nutrition and Soil Science, 163(2), 7.

Food and Agriculture Organization of the United Nations (FAO). (1999). Resource Document. FAO Agriculture and Consumer Protection Department. http://www.fao.org /ag/magazine/9901sp2.htm. Accessed 30 March 2007

Food and Agriculture Organization of the United Nations (FAO). (2008). Resource Document. FAO Land and Water Division. ftp://ftp.fao.org/agl/aglw/factsheet_ wwf_eng.pdf

Franz, C.M.A.P., Holzapfel, W.H., Stiles, M.E. (1999). Enterococci at the crossroads of food safety? International Journal of Food Microbiology, 47, 1-24.

Friedler, E. (2004). Quality of individual domestic greywater streams and its implication for on-site treatment and reuse possibilities. Environmental Technology, 25, 997-1008.

Gale, P. (2005). Land application of treated sewage sludge: quantifying pathogen risks from consumption of crops. Journal of Applied Microbiology, 98, 380-396.

Gerba, C.P., \& Smith, J.E. (2005). Sources of pathogenic microorganisms and their fate during land application of wastes. Journal Of Environmental Quality, 34, 4248.

Gracias, K.S., \& McKillip, J.L. (2004). A review of conventional detection and enumeration methods for pathogenic bacteria in food. Canadian Journal of Microbiology, 50, 883-890.

Gross, A., Azulai, N., Oron, G., Ronen, Z., Arnold, M. (2005). Environmental impact and health risks associated with greywater irrigation: a case study. Water science and technology, 52(8), 161-169.

Haas, C.N., Rose, J.B., Gerba, C.P. (1999). Quantitative Microbial Risk Assessment. New York, NY: John Wiley and Sons.

Hall, H.E., Brown, D.F., Angelotti, R. (1963). The Recovery of Enterococci from Food Using KF Streptococcus Media. Journal of Food Science, 28(5), 566-571.

Hernández-Leal, L., Zeeman, G., Temmink, H., Buisman, C. (2007). Characterisation and biological treatment of greywater. Water Science \& Technology, 56(5), 193200.

Hurst, C.J. (2002). Estimating the risk of infectious disease associated with pathogens in water. In Hurst, C.J., Crawford, R.L., Knudson, G.R., McInerney, M.J. and Stetzenbach, L.D. (eds.), Manual of Environmental Microbiology (2nd edn.), pp.309-319. Washington, DC: ASM Press. 
Ibiebele, D.D., \& Inyang, A.D. (1986). Environmental movement of indicator bacteria from soil amended with undigested sewage sludge. Environmental Pollution (Series A), 40, 53-62.

International Commission on Microbiological Specifications for Foods. (1986). Micro-organisms in foods 2: Sampling for microbiological analysis: Principles and specific applications. Toronto, ON: University of Toronto Press.

Jackson, S., Rodda, N., Salukazana, L. (2006). Microbiological assessment of food crops irrigated with domestic greywater. Water SA, 32(5), 700-704.

Jefferson, B., Burgess, J.E., Pichon, A., Harkness, J., Judd, S.J. (2001). Nutrient addition to enhance biological treatment of greywater. Water Research, 35(11), 2702-2710.

Jefferson, B., Palmer, A., Jeffrey, P., Stuetz, R., Judd, S. (2004). Grey water characterisation and its impact on the selection and operation of technologies for urban reuse. Water Science and Technology, 50(2), 157-164.

Jeppesen, B. (1996). Domestic greywater re-use: Australia's challenge for the future Desalination, 106, 311-315.

Jiang X., Morgan, J., Doyle, M.P. (2002). Fate of Escherichia coli O157: H7 in ManureAmended Soil. Applied and Environmental Microbiology, 68(5), 2605-2609.

Karami, M., Afyuni, M., Rezainejad, Y., Schulin, R. (2008). Heavy metal uptake by wheat from a sewage sludge-amended calcareous soil. Nutrient Cycling in Agroecosystems, 83, $51-61$.

Lazarova, V., Hills, S., Birks, R. (2003). Using recycled water for non-potable, urban uses: a review with particular reference to toilet flushing. Water science and Technology- Water Supply, 3(4), 69-77.

Mapanda, F., Mangwayana, E.N., Nyamangara, J., Giller, K.E. (2005). The effect of long-term irrigation using wastewater on heavy metal contents of soils under vegetables in Harare, Zimbabwe. Agriculture, Ecosystems and Environment, 107, 151-165.

Madungwe, E. \& Sakuringwa, S. (2007). Greywater reuse: A strategy for water demand management in Harare? Physics and Chemistry of the Earth, 32(15-18), 1231-1236.

Mills, R.G., Bartlett C.L., Kessel, J.F. (1925). The penetration of fruits and vegetables by bacteria and other particulate matter, and the resistance of bacteria, protozoan cysts and helminth ova to common disinfection methods. American Journal of Epidemiology, 5(5), 559-579.

Nolde, E. (1999). Greywater reuse systems for toilet flushing in multi-storey buildings-over ten years experience in Berlin. Urban Water, 1, 275-284.

Ortega-Larrocea, M.P., Siebe, C., Becard, G., Mendez, I., Webster, R. (2001). Impact of a century of wastewater irrigation on the abundance of arbuscular mycorrhizal spores in the soil of the Mezquital Valley of Mexico. Applied Soil Ecology, 16, 149-157.

Ottosson, J. (2003). Hygiene aspects of greywater and greywater reuse. Royal Institute of technology (KTH)/Swedish Institute for Infectious Disease Control (SMI), Stockholm: Licentiate Thesis.

Ottosson, J., \& Stenström, T.A. (2003). Growth and reduction of microorganisms in sediments collected from a greywater treatment system. Letters in Applied Microbiology, $36(3), 168-72$ 
Ottosson, J. (2005). Comparative Analysis of Pathogen Occurrence in WastewaterManagement strategies for barrier function and microbial control. Royal Institute of technology (KTH)/Swedish Institute for Infectious Disease Control (SMI), Stockholm: Doctorate Thesis.

Palmquist, H., \& Hanæus, J. (2005). Hazardous substances in separately collected grey- and blackwater from ordinary Swedish households. Science of the Total Environment, 348, 151-163.

Petterson, S.A., \& Ashbolt, N.J. (2003). WHO Guidelines for the Safe Use of Wastewater and Excreta in Agriculture: Microbial Risk Assessment Section. Resource document. http://www.who.int/entity/water_sanitation_health/wastewater/mrareview.pdf. Accessed 26 April 2007.

Pidou, M., Avery, L., Stephenson, T., Jeffrey, P., Parsons, S., Liu, et al. (2008). Chemical solutions for greywater recycling. Chemosphere, 71, 147-155.

Rattan, R.K., Datta, S.P., Chhonkar, P.K., Suribabu, K. (2005). Long-term impact of irrigation with sewage effluents on heavy metal content in soils, crops and groundwater - a case study. Agriculture, Ecosystems and Environment, 109, 310-322.

Roesner, L., Qian, Y., Criswell, M., Stromberger, M., Klein, S. (1994). Long-Term Effects of Landscape Irrigation Using Household Graywater- Literature Review and Synthesis. Resource Document. Water Environment Research Foundation. http://www.cleaning101.com/files/SDA_WERF_Graywater_2006.pdf. Accessed 20 January 2007

Rosas, I., Baez, A., Coutino, M. (1984). Bacteriological Quality of Crops Irrigated with Wastewater in the Xochimilco Plots, Mexico City, Mexico. Applied and Environmental Microbiology, 47(5), 1074-1079.

Rose, J.B., Sun, G-S., Gerba, C.P., Sinclair, N.A. (1991). Microbial quality and persistence of enteric pathogens in graywater from various household sources. Water Research, 25(1), 37-42.

Sadovski, A.Y., Fattal, B., Goldberg, D., Katzenelson, E. (1978). High levels of microbial contamination of vegetables irrigated with wastewater by the drip method. Applied and Environmental Microbiology, 36(6), 824-830.

Santamaría, J., \& Toranzos, G.A. (2003). Enteric pathogens and soil: a short review. International Microbiology, 6, 5-9.

Salgot, M., Vergés, C., Angelakis, A.N. (2003). Risk assessment in wastewater recycling and reuse. Water science and Technology- Water Supply, 3(4), 301-308.

Salgot, M., Huertas, E., Weber, S., Dott, W., Hollender, J. (2006). Wastewater reuse and risk: definition of key objectives. Desalination, 187, 29-40.

Surendran, S., \& Wheatley, A.D. (1998). Grey-water reclamation for non-potable reuse. Journal of the Chartered Institution of Water and Environmental Management, 12, 406-413.

Tierney, J., Sullivan, R., Larkin, E. (1977). Persistence of poliovirus 1 in soil and on vegetables grown in soil previously flooded with inoculated sewage sludge or effluent. Applied and Environmental Biology, 33(1), 109-113.

Toze, S. (2006). Reuse of effluent water-benefits and risks. Agricultural Water Management, 80, 147-159.

World Health Organization (WHO). (2006). Guidelines for the safe use of wastewater, excreta and greywater. Resource document. WHO. 
http://www.who.int/water_sanitation_health/wastewater/gsuww/en/index.html. Accessed 5 March 2007.

Wielshafran, A., Ronen, Z., Weisbrod, N., Adar, E., Gross, A. (2006). Potential changes in soil properties following irrigation with surfactant-rich greywater. Ecological Engineering, 26, 348-354. 


\section{APPENDIX A- COPYRIGHT WAIVER}

The following page consists of a copyright waiver signed by the co-authors of the article presented in this thesis: "Reuse of domestic greywater for the irrigation of food crops" which has been accepted for upcoming publication in the Journal of Water, Air, and Soil Pollution. 